\title{
Melhor o cozinheiro? \\ Um percurso sobre a dimensão de gênero da preparação da comida (Europa ocidental, séculos XVI-XIX)*
}

\author{
Raffaella Sarti**
}

\section{Resumo}

Este artigo analisa a preparação da comida na Europa ocidental (séculos XVI a XIX), enfocando sua dimensão de gênero. São consideradas três principais variáveis: estratificação social, geografia e tempo. Sugere que na Itália, Espanha e França, no início do período moderno, os cozinheiros empregados nas cortes e pela aristocracia eram geralmente homens; a feminização da preparação da comida começou na França a partir do século XVIII. Na Europa central e do norte, as mulheres das classes mais altas estavam muito mais envolvidas na preparação da comida, embora a moda da cozinha francesa nos séculos XVII e XVIII tenha implicado no recurso crescente de homens cozinheiros. $\mathrm{O}$ artigo sugere explicações para essas diferenças e tendências através dos tempos, e discute o papel da nutrição e cozinha na definição da identidade feminina em contextos diferentes.

Palavras-chave: Gênero, Preparação Culinária, Livros de Cozinha, Europa, 1500-1800.

" Recebido para publicação em 08 de junho de 2012, aceito em 25 de junho de 2012. Tradução: Matteo Raschietti; revisão técnica: Wanessa Asfora.

"* Professora de História Moderna, Universidade de Urbino "Carlo Bo", Itália. raffaella.sarti@uniurb.it

cadernos pagu (39), julho-dezembro de 2012:87-158. 
Melhor o cozinheiro?

A male cook, is it better? An overview on the gender dimension of cooking (Western Europe, $16^{\text {th }}$ to $19^{\text {th }}$ centuries)

\begin{abstract}
This paper analyses the preparation of food in Western Europe $\left(16^{\text {th }}-19^{\text {th }}\right.$ centuries $)$, focusing on its gendered dimension. Three main variables are considered: social stratification, geography and time. It suggests that in Italy, Spain and France in early modern times the cooks employed at the courts and by the aristocracy were generally men; a feminization of the preparation of food started in France from the 18th century onwards. In Central and Northern Europe women were much more involved in the preparation of food in the upper classes, too, even though the fashion for French cuisine in the $17^{\text {th }}$ and $18^{\text {th }}$ centuries implied a growing recourse to male cooks. The paper suggests explanations of these differences and trends over time and discusses the role of nurturing and cooking for the definition of the female identity in different contexts.
\end{abstract}

Key Words: Gender, Preparation of Food, Cookery Books, Europe, 1500-1800. 


\section{Introdução}

A história da alimentação em suas múltiplas facetas - o tipo de comidas em diferentes momentos históricos, geográficos, sociais, culturais; métodos de preparação e consumo da comida; boas maneiras e convívio à mesa, etc. - é objeto de grande interesse nos últimos anos. Este artigo $^{1}$ é uma contribuição para esse rico campo de estudos. Ao mesmo tempo, tem como objetivo enriquecer o conhecimento da divisão dos papéis e tarefas entre homens e mulheres, bem como, mais em geral, a reflexão sobre a identidade de gênero entendido como construção cultural variável de acordo com lugares, períodos, grupos sociais e culturas.

Mais especificamente, o trabalho investiga a dimensão de gênero da preparação da comida na Europa (ou, mais

1 O artigo é uma revisão e uma ampliação de um texto elaborado, em sua primeira versão, no meu volume Vita di casa. Abitare, mangiare, vestire nell'Europa moderna (Sarti, 1999:264-282) e apresentado em seguida, em uma versão revisada, no congresso La cucina di casa in Italia, dal medioevo ad oggi que foi realizado durante a sexta edição da Festa Artusiana (Forlimpopoli, Itália, 22 de junho de 2002), uma celebração anual em honra de Pellegrino Artusi, autor do livro de cozinha italiano mais importante, La scienza in cucina e l'arte di mangiar bene (Artusi, 1891). As atas do congresso estão disponíveis no site http://www.pellegrinoartusi.it/convegni-artusiani-2/2002-2/. Em seguida, questões aqui tratadas foram objeto de uma parte do curso que ministrei em Viena no ano letivo 2006-2007 como Käthe Leichter visiting professor (Zur Geschichte der materiellen Kultur: Die Modernisierung des Haushaltes) [Professora visitante (Sobre a história da cultura material: a modernização do cuidado do lar)]. Em comparação com as versões anteriores, o texto apresentado aqui foi aumentado e reelaborado. A transcrição dos títulos das obras antigas citadas, consultadas durante um longo período, não segue um critério uniforme. Muitos dos livros de cozinha citados existem em edições recentes e reimpressões anastáticas, às vezes citadas, mas não sistematicamente. Para verificações desse tipo, é útil o site http://www.notaker.com/bibliogr/reprfacs.htm. Nas referências bibliográficas finais são indicados os textos em relação aos quais são feitas referências específicas; outros textos, acenados apenas em modo genérico, são citados por extenso nas notas e no texto, sem ser citados na bibliografia. Agradeço Carmen Abad Zardoya, Andrea Addobbati, Patrizia Delpiano e Tessa Storey pelas sugestões e auxílio em encontrar textos e imagens. 
Melhor o cozinheiro?

corretamente, na Europa ocidental) ao longo do período que vai do fim da Idade Média ao século XIX. Com base na análise de diferentes fontes e dos resultados dos estudos conduzidos, sugere que, no período examinado, havia diferenças importantes - entre Itália, França e Espanha, por um lado, e os países da Europa Central e do Norte, por outro -, relativas à divisão do trabalho de cozinha entre homens e mulheres nas casas das famílias no topo da escala social. Além disso, sugere que, ao longo do tempo, ocorreram transformações relevantes dessa divisão do trabalho. Dessas diferenças e transformações, o ensaio procura, naturalmente, dar uma explicação.

\section{A cozinha da casa Albergati}

No dia 18 de agosto de 1786, um cavalheiro e homem de letras de Bolonha, Francesco Albergati Capacelli, estava no seu palácio de campo em Zola Predosa, próximo à cidade. ${ }^{2}$ Dia infausto: sua mulher foi encontrada em uma poça de sangue com uma faca no peito. Suicídio ou homicídio? Suicídio, concluíram os juízes, mas o caso ainda hoje permanece um mistério. Durante a investigação foram interrogados todos os servos da casa, e sendo que o crime acontecera pouco depois da hora do almoço, todos explicaram como, onde e com quem tinham comido ou estavam comendo. Uma vez que as atas do processo volumoso foram conservadas, sabemos quem disse que estava na cozinha. Com base nos depoimentos, a cozinha estava um tanto apinhada. Portanto, não parece muito provável que alguém tenha dito, mentindo, que estava lá na hora do crime, a não ser que se queira admitir que muitos haviam combinado antes. Todos, no entanto, foram obrigados a dar uma versão dos fatos que os investigadores achassem plausível, o que é importante para nós.

Eis então quem disse que estava na cozinha: os criados Gaetano Barselli e Andrea Bontà, o cozinheiro Antonio Ungarelli,

2 Para informações sobre essa residência, cf. http://www.albergati.com/it/?LN=IT. 
o segundo cozinheiro Gesualdo Pasudetti, o servo Antonio Ercolin. E depois ainda Giacomo Merli, o trabalhador braçal que morava de aluguel em uma casa do senador e que no verão, durante o período em que este vivia no campo, trabalhava ao seu serviço. ${ }^{3}$ Gaetano, Andrea, Antonio, Gesualdo, outro Antonio, Giacomo... $\mathrm{Na}$ cozinha, portanto, de acordo com os testemunhos, só havia homens. Eram homens, em particular, o cozinheiro e o segundo cozinheiro. Com certeza esse não era um caso isolado, nem em Bolonha nem nas outras partes da Itália. $\mathrm{Na}$ Idade Moderna, com efeito, nas famílias das elites a preferência para os cozinheiros homens era generalizada, como se deduz da análise das diversas fontes - desde os status animarum aos livros de contas, desde os tratados de cozinha às cartas pessoais, só para citar alguns exemplos - que nos dão informações sobre a composição do pessoal doméstico ao serviço das famílias no topo da escala social. ${ }^{4}$

\section{Melhor o cozinheiro}

"Ousaria [...] afirmar, que a coisa melhor seria ter um Cozinheiro Homem antes que uma Mulher", escrevera na metade do séc. XVII outro cavalheiro bolonhês, Vincenzo Tanara, na sua Economia del cittadino in villa (Tanara, 1648:158) ${ }^{5}$, um livro que fornecia indicações para uma boa gestão econômica das casas de campo, mas também, em parte, para as casas da cidade. Quiçá se Albergati lera o volume de Tanara - texto de enorme sucesso

${ }^{3}$ Arquivo de Estado de Bolonha, Tribunale criminale del Torrone, Atti processuali, 8374/5, fasc. 100 .

${ }^{4}$ Capatti e Montanari (1999:273-278); Sarti (1994a:55-85; 2001:262-282); Muzzarelli, 2003, etc.

${ }^{5}$ Esse trecho do texto de Tanara (extraído, porém, da edição veneziana de 1655) está reproduzido parcialmente em Montanari (1991:209-211). Outra edição bolonhesa, junto aos herdeiros de Dozza, de 1651, está disponível em: http://books.google.com. Da obra de Tanara, além disso, há duas reimpressões anastáticas recentes (Bologna, Li Causi, 1983 e Bologna, Analisi, 1987). 
reimpresso ainda em $1761^{6}$ - e seguia suas indicações. ${ }^{7}$ Seja como for, para as finalidades do discurso que visamos desenvolver aqui, vale a pena deter-nos sobre as motivações aduzidas por Tanara para justificar sua preferência para os cozinheiros homens.

As mulheres, em sua opinião, são "beberronas, caluniadoras, ou bruxas", ladras e esbanjadoras. Aquele que trabalha na cozinha tem que ser

limpo, fiel \& entendedor. Quem não sabe que, normalmente, está mais limpo o mais sujo dos Homens, do que a mais limpa das Mulheres? A Cozinheira, colocada a panela no fogo, arruma os cabelos, depois, enquanto os alimentos cozinham fia com os dedos todos cuspidos (Tanara, 1648:158).

E o que dizer a respeito da inteligência? "Comparar a inteligência habitual de um homem com aquela da mulher, é grande injúria ao nosso sexo" (id.ib.), sentencia o autor. E prossegue desfilando um amplo catálogo de argumentações misóginas para sustentar a preferência que deve ser reservada aos cozinheiros homens.

\section{Mulheres nutrizes por natureza?}

Esse rol de argumentações misóginas hoje pode provocar risos. Ao mesmo tempo, contudo, surpreende e faz pensar, pois associa a preparação da comida aos homens mais do que às mulheres, enquanto em muitas sociedades contemporâneas muitas vezes admite-se sem discussão que, no passado, a preparação da comida fosse uma tarefa feminina. E, às vezes, sustenta-se até que o ato de cozinhar seria uma espécie de extensão do papel "natural" das mulheres como mães e nutrizes de seus filhos: nessa perspectiva, em suma, entre a mulher que

${ }^{6}$ O volume teve um enorme sucesso. Eu contei dezessete edições entre 1644 e 1761.

7 Sobre a formação cultural de Francesco Albergati Capacelli, cf. Mattioda, 1993. 
amamenta sua criança $e$ a mulher no fogão não haveria solução de continuidade. ${ }^{8}$

"As mulheres por natureza amamentam e, portanto, são levadas naturalmente a alimentar e a cuidar da comida": uma frase como essa, para um homem como Tanara, provavelmente pareceria duplamente errada. Em primeiro lugar porque, nos ambientes onde ele vivia, as mulheres raramente amamentavam suas crianças - naquela época, entre os aristocratas italianos, as madames entregavam as crianças a uma ama. As mulheres italianas da elite, com efeito, teriam começado timidamente a amamentar seus filhos só no século XVIII. ${ }^{9}$ Longe de mencionar o corpo das mulheres - com sua capacidade de gerar e alimentar como ponto de apoio para uma suposta predisposição feminina para a preparação da comida, Tanara evoca outro aspecto, a menstruação, a fim de sustentar suas argumentações misóginas. Com falsa discrição, acena implicitamente a ela: "outras coisas naturais para as Mulheres [...], das quais em tudo, e por tudo o Homem está livre" (Tanara, 1648:158). E, significativamente, a menciona no trecho em que fala da pouca limpeza das cozinheiras, a fim de reforçar evidentemente no leitor uma sensação de nojo e repugnância para com as mulheres na cozinha. ${ }^{10}$

Mas a frase citada acima, para um homem como Tanara, provavelmente pareceria infundada também por outro motivo. $\mathrm{O}$ autor seiscentista, com efeito, não vê o fato de preparar a comida, ou pelo menos de preparar bem a comida, como algo natural.

8 Sobre a relação mulheres/comida, cf. por ex. Maffia, 1998; Muzzarelli, Tarozzi, 2003 e o site: http://www.women.it/spaziodonna/bibliografia.html.

9 Klapisch-Zuber (1988:213-252); Barbagli (1996:336-363); D’Amelia, 1997; Fiume (1997:90-97); Sarti, 1999. Mais em geral, sobre a história da amamentação e da criação cf. Fildes, 1986; Id., 1988; Matthews Grieco, 1991; Lett, Morel 2006; Pech 2007, etc.

${ }^{10} \mathrm{Na}$ Roma antiga, como em muitas outras culturas, achava-se que a mulher menstruada contaminasse a comida e tivesse, sobre ela, efeitos negativos, cf. Deonna e Renard, 1994:45-48. 
Melhor o cozinheiro?

Não por acaso, entre as muitas razões aduzidas para justificar por que seria melhor ter cozinheiros antes que cozinheiras, explica que as mulheres têm menos habilidades do que os homens porque

chegam a esta profissão em idade madura [= adulta], pela qual coisa não podem tornar-se tão aptas, como os Homens, que desde moços, com o saltério de virar o espeto, ou a tábua para lavar a louça, treinam aos poucos, e aguentam os fogos, solícitos e experientes em ocasião de hóspedes inesperados [repentine Foresterie].

Em suma, segundo o autor seiscentista, a cozinha é uma arte que deve ser apreendida precocemente, se se quer alcançar bons resultados. A natureza não tem nada a ver. Ou melhor: tem a ver no sentido de que a "lentidão natural" das mulheres torna particularmente difícil sua instrução: "se hoje você lhes ensinar uma coisa, amanhã não lembram mais" (Tanara, 1648:158-159).

\section{Pessoas de confiança}

Entre as várias razões para a preferência reservada aos homens na preparação da comida e no serviço de mesa pelas camadas sociais no topo da sociedade, deve ser incluída a importância especial que tinha a esfera da alimentação, seja do ponto de vista material, seja do ponto de vista simbólico. Devido à sua importância, as várias atividades relacionadas com a cozinha e a mesa tinham que ser entregues a pessoas de confiança, que em uma sociedade organizada sobre fortes hierarquias $e$ assimetrias de gênero entre homens e mulheres como a do Antigo Regime - de preferência eram de sexo masculino. De fato, o bemestar e a vida do dono, da sua família e dos seus hóspedes, dependiam muito da competência técnica e da confiabilidade do pessoal da cozinha e da sala de jantar.

Os envenenamentos, em particular, eram muito temidos, como demonstram inclusive numerosos contos de fadas europeus em que o cozinheiro é um assassino a serviço de um patrão 
infernal e canibal (Milillo, 1994:54; Cusatelli, 1994). A Itália do Renascimento e, principalmente, a Roma papal e Veneza, passaram à história como contextos em que o uso do veneno era particularmente difundido, por um lado, e temido do outro (Pastore, 2010:17-47). No idioma italiano, significativamente, tanto o móvel sobre o qual eram apoiadas as comidas frias e os pratos, quanto a modalidade de servir os alimentos sem tocá-los com as mãos, segurando-os com dois guardanapos, com dois pedaços de pão ou com dois pratos, tinham o mesmo nome de credenza [em português aparador, ndT], derivado do verbo latim credo, dar confiança: a exibição da ausência de contato entre as mãos e a comida visava garantir aos comensais que podiam confiar em quem os estava servindo; de modo semelhante, o costume de manter rigorosamente debaixo da vista o móvel sobre o qual se apoiavam pratos e comidas frias tinha a finalidade de garantir a confiança daquilo que era levado à mesa (Manciulli, 1997:329). ${ }^{11}$

"Fazer a credenza" significava fazer "o teste do veneno", e credenzino era definido o pedacinho de miolo do pão mergulhado no prato e experimentado, para verificar que a comida não fosse tóxica, pelo cozinheiro, pelos paggi [servos], pelo scalco [cortesão que cuidava do banquete] e pelo trinciante [cortador da carne] (Bemporat, 2007:18). Mas se a confiança em todas suas diferentes facetas e declinações era crucial na esfera da preparação e do consumo da comida, as acusações que Tanara fazia às cozinheiras se baseavam em uma impossibilidade presumida de confiar nas mulheres na cozinha, seja porque eram incompetentes e incapazes

\footnotetext{
${ }^{11}$ Segundo Cortelazzo e Zolli (1979:295), "credenza (móvel) é uma evolução semântica ulterior em relação ao significado que a palavra tinha antigamente de "experimentação das comidas destinadas a um grande personagem para demonstrar que não estavam envenenadas"'. Na origem credenze [aparadores] eram simples mesas sobre as quais se apoiavam pratos, vasilhas e comidas. Pelo fato de a riqueza das vasilhas ser um indicador de status que todos deviam ver, $e$ com abundância, começou-se a construir prateleiras a fim de que estivessem bem à mostra: o mesmo número de prateleiras se tornou uma indicação da condição do dono de casa, cf. Thornton, 1992:207 e 220-221; Montenegro, 1996:68.
} 
Melhor o cozinheiro?

de cozinhar bem; seja porque eram fontes de contaminações potenciais das comidas por causa da sua falta de higiene $e$ desmazelo; seja porque eram perigosas por sua vontade precisa de prejudicar; seja por outros motivos. Em 1643, portanto o ano anterior à primeira edição da Economia do citadino na casa de campo, de Tanara, foi publicada em Florença a segunda edição de uma obra trabalhosa editada pela primeira vez cinco anos antes, Il Giudice Criminalista, de Antonio Maria Cospi, secretário do GrãoDuque de Toscana. Na obra, como explicava a folha de rosto, "fala-se de todas aquelas coisas que podem acontecer ao Juiz das causas criminais". Naturalmente muitas páginas eram dedicadas a venenos e envenenamentos. E todo um capítulo explicava que "as mulheres têm mais facilidade em dar veneno" do que os homens:

se deste delito for acusada alguma mulher, o Juiz poderá mais facilmente acreditar: porque tendo a mulher um ânimo vil [...] e não podendo ela com a força, procura vingar-se do modo mais ímpio que seu pensamento lhe apresenta.

O autor sustentava suas afirmações com referências bíblicas e citações clássicas (Cospi, 1643:455). De fato, uma tradição muito antiga associava as mulheres, mais do que os homens, ao uso do veneno, que era oferecido principalmente junto a bebidas ou comidas (Pastore, 2010:50-52, 134). Não faltam exemplos de mulheres que parecem confirmar o estereótipo: é o caso de Prudenza de Trani, decapitada em 1549 em Florença por ter envenenado o marido (id.ib.:94); ou também - em um período muito mais tarde - é o caso das mulheres de Palermo que, no final do século XVIII, se livraram dos maridos dando-lhes um "vinagre" particular fornecido por uma velha, Giovanna Bonanno, que tinha se "especializado" nesse setor, fato único, e que depois foi processada por bruxaria e condenada à morte (Fiume, 2008, 1990). Apesar da grande repercussão desses casos, parece provável que as mulheres não fossem mais propensas do que os homens para lançar mão do veneno e que, substancialmente, essa convicção, 
embora muito enraizada, era um preconceito não confirmado pela realidade (Pastore, 2010:100-101).

A manipulação de ervas, de pós e de outras substâncias oferecidas como (ou junto a) alimentos e bebidas, remetia a uma variedade de práticas que visavam alcançar resultados que iam da nutrição à cosmética $e$ às curas, dos encantamentos aos envenenamentos. Não raro, contudo, encontrava-se em uma fronteira incerta entre cozinha, cosmética, medicina e magia. Ingredientes de poções e filtros podiam ser substâncias, se não tóxicas, pelo menos nojentas: entre elas, era usado particularmente o sangue menstrual (Muzzarelli, 2003:14-15; Malaguti, 2005:14, 47-48), que o próprio Tanara aludira. Além do mais, a fronteira entre práticas consideradas socialmente aceitáveis e práticas consideradas feitiçarias era fugaz: por um lado, entre o fim da Idade Média e a Idade Moderna, com a consolidação do conhecimento médico "oficial" (masculino), as mulheres que preparavam poções e unguentos cada vez mais facilmente corriam o risco de serem acusadas de bruxaria; por outro, o imaginário popular representava as bruxas como mulheres atarefadas ao redor de panelas e caldeirões a fim de preparar poções e filtros (Muzzarelli, 2003:18-29; Pastore, 2010:51). Considere-se, só para citar um exemplo quase contemporâneo aos textos que mencionamos até agora, o quadro do pintor napolitano Salvador Rosa cujo título é Streghe e incantesimi (1646, National Gallery, Londres), no qual se vê em primeiro plano uma bruxa nua sentada no chão mexendo em um vaso diante de si. ${ }^{12}$ Não por acaso, nas palavras de Tanara vislumbra-se o receio de que nas cozinhas podiam circular algumas bruxas ("beberronas, caluniadoras, ou bruxas").

Mas mesmo as mulheres piedosas e de caridade, potencialmente santas, podiam levantar suspeitas na cozinha: Tanara alertava contra a tendência feminina de dar esmola com os bens do patrão: "A mulher Cozinheira [...] às vezes dá esmola com aquilo que lhe rouba" (Tanara, 1648:158). De fato havia mulheres,

${ }^{12}$ Veja, por exemplo: http://jizaino.net16.net/ita/opere/rosa_a.html. 
Melhor o cozinheiro?

inclusive alçadas às honras dos altares, que tinham distribuído os bens dos patrões como esmola aos pobres, principalmente alimentos; é o caso de Zita, servidora do século XIII junto à família Fatinelli de Lucca, oficialmente canonizada no final do século XVII ex cultu immemorabili. Esses comportamentos, que expressavam um tipo de religiosidade de cunho mendicante, durante a Idade Moderna e, mais ainda, no século XIX, seriam vistos com grande desconfiança e os serviçais não seriam encorajados à caridade aos pobres, mas à máxima fidelidade aos patrões "nas coisas". ${ }^{13}$ Significativamente, mesmo no que diz respeito às propriedades do patrão, aos olhos de Tanara, as mulheres apareciam piores do que os homens: o homem "será sempre mais fiel do que a Mulher", sentenciava. E isso não só porque as mulheres davam esmola, mas também porque demonstravam uma tendência mais acentuada, em sua opinião, a desperdiçar comida ou a subtraí-la para distribuir a familiares, amigas e amantes. Além disso, a consciência de serem punidas e sancionadas com menos severidade do que os homens, caso roubassem, as tornaria mais propensas ao roubo (Tanara, 1648:158). Tanara, em suma, detia-se em uma descrição do pessoal da cozinha obscuramente gendered. Graças ao cruzamento com outras fontes, é possível verificar que muitas das ideias $e$ dos preconceitos sobre os homens $e$ as mulheres que o autor colocava em cena não eram fruto só das suas idiossincrasias pessoais, mas expressavam convicções amplamente difundidas. No repertório da misoginia da época não faltavam, por exemplo, representações desoladoras das cozinheiras. Em um soneto intitulado Contra le donne, a uma cozinheira suja e infame era atribuída a culpa pelo fato de São Pedro ter renegado Jesus: "Não tem juízo, ou razão, quem acredita em Mulher, // Enquanto uma infame, suja Cozinheira // Fez com que Pedro renegasse a fé" (Loredano, 1669:183). Obviamente, por

\footnotetext{
${ }^{13}$ Para alguns exemplos de incitamentos à fidelidade "nas coisas" cf. Ferrini (1607, II parte:300); Fontana (1710:21); sobre Zita cf. Sarti (1994b,2007).
} 
um lado, como se sabe, havia quem criticasse tanta misoginia. ${ }^{14}$ Mas, do outro, a difusão de estereótipos e preconceitos, mais ou menos amplamente contestados, nos permite captar alguns aspectos importantes da construção sócio-cultural da identidade de gênero entendida, justamente, como fruto de dinâmicas conflitivas. E se a lista das argumentações misóginas de Tanara não acaba aqui, continuando a segui-lo, são introduzidos outros assuntos relevantes para compreender o papel de homens $e$ mulheres na esfera da preparação e dos modos de consumo da comida na Idade Moderna.

\section{Um teatro do poder}

"Se em ocasião de um convidado que vem de fora, ou de outra causa, se quer sair do ordinário, [as mulheres] estão perdidas, enroladas, e fazem tudo ao avesso", afirma Tanara. Por quê? Porque são "por natureza grosseiras, toscas". Em suma, quando um senhor quer impressionar seus hóspedes não pode esperar ter sucesso se tiver cozinheiras ao seu serviço: mesmo admitindo que elas são adequadas para a cozinha de todos os dias, com certeza não saberiam lidar com eventos excepcionais (Tanara, 1648:158-159). E essa é uma limitação gravíssima em uma sociedade que atribui aos banquetes, entendidos como momentos privilegiados daquela exibição de fasto e riqueza que desempenha um papel tão importante na gestão do poder durante o Ancien régime. Aparadores e prateleiras em exibição carregados de vasilhas de prata, dezenas de comidas, centenas de pratos prontos transformados em maravilhas por artifícios engenhosos: estátuas grandiosas de manteiga, "hidras de sete cabeças de massa folhada", pavões $e$ faisões revestidos com suas plumas $e$ "enfeitados de pérolas, corais e pequenas fatias de ouro e de prata", cavalos, touros ou outros animais assados de onde saem

${ }^{14}$ Veja, por exemplo, o contexto no qual está inserido o soneto citado, Loredano (1669:183). Para uma história das mulheres voltada para a querelle des femmes cf. G. Bock, 2001. 
Melhor o cozinheiro?

aves, lebres, coelhos vivos, "crianças feitas com açúcar", castelos e navios de massa, e depois, ainda, fontes espetaculares de vinho... Os banquetes são um teatro em que os poderosos encenam sua posição de prestígio e, desse modo, a confirmam e a consolidam. Especialmente no começo da Idade Moderna, não faltam espectadores para assistir. ${ }^{15}$

Para funcionar, máquinas tão complexas exigiam pessoal não apenas de confiança, mas também competente e, poderíamos dizer, com nervos sólidos. Investidos de grande responsabilidade para garantir o sucesso de manifestações carregadas de implicações e valores sociais, os cozinheiros $e$ os funcionários encarregados da comida eram submetidos a uma pressão psicológica intensa, com resultados às vezes devastadores. É bem conhecido o caso do suíço Fritz Karl Watel, chamado Vatel, responsável pelas provisões e pela preparação da mesa do príncipe de Condé. Em 1670, quando o príncipe convidou Luís XIV para visitá-lo em seu palácio de Chantilly, Watel se convenceu - erradamente - que o peixe que devia ser cozinhado não tinha chegado. Em desespero, matou-se, incapaz de suportar o peso esmagador de tamanha desonra: sua e também do seu patrão. ${ }^{16}$

Em suma, a honra de uma casa, ou uma parte dela, dependia também da competência e da confiabilidade do pessoal encarregado da comida. De modo especular, as várias atividades que visavam garantir o sucesso dos banquetes podiam ser uma fonte de honra para aqueles que as executavam, particularmente

${ }^{15}$ As citações provêm de Vincenzo Cervio, Il trinciante [O que corta as carnes], Roma, Gabbia, 1593 [1581] e de Bartolomeo Stefani, L'arte di ben cucinare [A arte de cozinhar bem], Mantova, Osanna, 1662 e Venezia, Giovan Giacomo Hertz, 1666. Os dois textos são reproduzidos em Faccioli, 1992, as citações provêm, respectivamente, das pp. 528-537 e pp. 676-682. Sobre o papel dos banquetes, cf. Faccioli, 1973; Calvi e Bertelli, 1983; Bertelli e Crifò, 1985; Bentini et alii, 1988; Fragnito, 1991; Ricci, 1994; Montanari, 1994; Manciulli, 1997; Romani, 1997; Taylor, 2005; Albala, 2007; Bemporat, 2007; Dickie, 2007 etc.

${ }^{16}$ M. de Rabutin-Chantal, Lettres, org. E. Gérard-Gailly, Gallimard, Paris 1953, I, pp. 232-236, in Montanari, 1991:231-233; Fairchilds, 1984:28-31. Sobre a figura de Vatel cf. Michel, 1999. 
as que ocorriam em público (como o serviço de mesa nos banquetes que aconteciam nas moradias aristocráticas $e$ principescas).

Três são os ofícios honrados que costumam dar os grandes Príncipes para o cuidado da sua boca; isto é, o Scalco [cortesão que cuidava do banquete], o Coppiere [copeiro] $e$ o Trinciante [cortador da carne ${ }^{17}$ : é costume confiar cada um desses ofícios a pessoas muito nobres, de confiança, e de casa (Cervio, 1593:1-2),

escreveu Vincenzo Cervio no final do séc. XVI. ${ }^{18}$

Ao fornecer indicações para a economia do morador da cidade na casa de campo, Tanara, cinquenta anos mais tarde, dirigia-se a um público diferente dos "grandes príncipes" de que falara Cervio. Ele também, no entanto, demonstrava-se sensível para a eficiência e a estética do serviço à mesa. E, mais uma vez, sua sensibilidade correspondia a esquemas rígidos de gênero. Entre as argumentações em favor da escolha da equipe de cozinha de sexo masculino, ele não deixava de lembrar as vantagens que oferecia também desse ponto de vista: "este prepara os alimentos, leva-os à mesa, gira ao redor dela, coisa que não é decente para as Mulheres, nem mesmo se sabem achar o tempo" (Tanara,

${ }^{17} \mathrm{O}$ scalco tinha a tarefa de coordenar o trabalho de todos aqueles que se ocupavam com a alimentação da casa e de dirigir o serviço à mesa do senhor. $\mathrm{O}$ coppiere servia a bebida ao senhor durante a refeição e o trinciante tinha que cortar as comidas nos banquetes.

${ }^{18}$ Segundo Fragnito (1991:155), a importância crescente assumida pelos banquetes durante o século XVI envolveu um prestígio crescente e recompensas maiores para os encarregados da mesa (em particular, justamente, scalchi e trincianti). Cervio (1593:2), no entanto, se por um lado realçava o prestígio desses papéis, por outro lamentava que na sua época conhecera uma certa decadência, particularmente na corte de Roma. Messisbugo, ativo como scalco na corte de Ferrara, em 1533 fora nomeado conde palatino por Carlo V; Domenico Romoli parece que era um cavalheiro florentino, cf. Faccioli, 1992, 1987:255, 359. 
Melhor o cozinheiro?

1648:159). Parece estar vendo estes homens que dançam com bandejas e pratos de comida...

\section{Homens e mulheres na cozinha: gender, class and nation(ality)}

A Itália (e um aceno à Espanha)

Antes que eu comece a raciocinar, isto só se deve saber, que eu não gastarei tempo, ou energias para descrever várias soupas de hortaliças, ou legumes, e ensinar a fritar uma tenca, ou assar um lúcio na grelha, ou coisas semelhantes, que qualquer mulherzinha vil sabe fazer otimamente. Mas falarei somente das comidas finas, e mais importantes (Messisbugo, 1600:39v).

Nessa frase, muitíssimo citada, Cristoforo Messisbugo, autor de um dos mais importantes livros de cozinha do Renascimento, reimpresso pelo menos dez vezes entre 1549 e 1624, não desaconselhava lançar mão das cozinheiras, como um século mais tarde teria feito Tanara, mas distinguia entre uma cozinha diária, praticada pelas mulheres, e uma cozinha "alta" e refinada, que, por contraste, era definida usando o gênero masculino. Com efeito, os autores dos tratados de cozinha que forneciam indicações e receitas para as cozinhas das casas mais nobres $e$ ricas, na sua maioria (mas não só ${ }^{19}$ ), eram homens: considere-se, só para citar os autores de maior sucesso -, ao lado dos já mencionados Messisbugo e Tanara - o Mestre Martino de Como, autor em meados do século $\mathrm{XV}$ do Libro de arte coquinaria; Bartolomeo Sacchi, conhecido como Platina, que escreveu o De honesta voluptate, publicado pela primeira vez em Roma, talvez em 1474; Domenico Romoli, chamado Panunto (La singolar dottrina, Venezia, Michele Tramezzino, 1560); Bartolomeo Scappi (Opera, Venezia, Michele Tramezzino, 1570); Vincenzo Cervio (Il

${ }^{19}$ Por ex. Frugoli, 1638: folha de rosto: Pratica, e Scalcaria d'Antonio Frugoli lucchese, intitolata Pianta di Delicati Frutti Da servirsi à qualsivoglia Mensa di Prencipi e gran Signori, \& à Persone ordinarie ancora... 
trinciante, Venezia, Eredi di Francesco Tramezzino, 1581); Antonio Frugoli (Pratica e Scalcaria, Roma, Francesco Cavalli, 1631); Bartolomeo Stefani (L'Arte di ben cucinare, Mantova, Osanna, 1662) ou Antonio Latini (Lo scalco alla moderna, Napoli, Dom. Ant. Parrino e Michele Luigi Mutii, 1692). Escritos por homens, esses tratados dirigiam-se a homens e falavam de homens: cortadores, trincianti, responsáveis pelo vinho, cantineiros, garrafeiros, fabricantes de aparadores, cozinheiros, segundos cozinheiros, ajudantes de cozinha, encarregados das compras... ${ }^{20}$

$\mathrm{E}$ as mulheres? Nas palavras de Messisbugo vislumbrava-se uma atitude complexa para com as mulheres na cozinha, por um lado de desprezo ("qualquer mulherzinha vil"), mas também, por outro, de apreciação, na medida em que o grande cozinheiro indiretamente reconhecia às mulheres a capacidade de preparar "otimamente" certos pratos, ainda que simples. Muitas fontes confirmam que nas familias de classe média e baixa a preparação da comida, ao contrário daquilo que ocorria nos palácios da elite, era feita por mulheres, mães de família, filhas ou servas que fossem - entendendo-se que os mais pobres, que nem tinham dinheiro para comprar o combustível, ou que viviam em quartos miseráveis sem lareira, ou que até eram sem-teto, normalmente não cozinhavam. Se e quando tinham a possibilidade, iam às tabernas ou compravam comidas já preparadas (em primeiro lugar o pão) nas lojas, com os vendedores na rua, com as mulheres que complementavam a renda familiar vendendo as comidas que preparavam para os transeuntes. Ou, também, contentavam-se com as esmolas que davam algumas pessoas de caridade ou as instituições responsáveis para socorrer os pobres (Sarti, 1999; Ago, 2006:87-93; Cavallo, 2006:75; Storey, 2011).

Uma estampa (talvez do início do séc. XVIII) do gravador bolonhês Giuseppe Maria Mitelli (1634-1718) dedicada a Il gioco delle donne e sue facende ${ }^{21}$, embora com um estilo bem-

\footnotetext{
${ }^{20}$ Os textos citados são parcialmente reproduzidos em Faccioli, 1992.

${ }^{21} \mathrm{http}: / / w w w . g a r i s e n d a . i t / c a t a l o g h i / c a t a l o g o \_s t a m p e /$ pagina26668.html
} 
Melhor o cozinheiro?

humorado, faz uma lista de atividades femininas decididamente verossímil, e entre elas não faltam a preparação da comida, a alimentação do filho pequeno com a papinha, a arrumação da mesa. Vejamos, portanto, alguma das fontes que confirmam o papel das mulheres na cozinha, dando uma ideia de sua variedade, no lugar de analisar apenas uma em modo sistemático. "E na terça-feira seguinte, de manhã, a ajudei a preparar o pão", contou em 1626, por exemplo, uma serva do interior, Sabbatina Masini, aos juízes do tribunal criminal de Bolonha que a interrogavam durante um processo em que era acusada de infanticídio, relatando a ajuda que, segundo ela, tinha dado a uma certa Giacoma Orsona. Como no caso do interrogatório relativo ao processo Albergati, citado no início, não podemos excluir que Sabbatina estivesse mentindo; ela, entretanto, devia necessariamente contar uma história que fosse crível: e aos ouvidos dos juízes não devia parecer estranho que uma serva do interior ajudasse outra mulher a preparar o pão. ${ }^{22}$ "Eu preparo um pão que todo mundo gosta" e "uma comida saborosa e delicada", declarava a "mulher como se estivesse narrando suas virtudes à procura de um patrão", cujas vicissitudes são narradas em La fantesca, do poeta burlesco senês Bastiano de Francesco - uma composição das primeiras décadas do século XVI cheia de insinuações sexuais enredadas, porém, com a atividade concreta das servas, para citar uma fonte totalmente diferente. ${ }^{23}$ De modo semelhante, em La massera da be', a pobre mulher da roça na província de Brescia, protagonista de uma composição dialetal de Galeazzo degli Orzi (1554), oferecendo seus serviços enumera os

\footnotetext{
${ }^{22}$ Arquivo de Estado de Bolonha, Tribunal criminal do Torrone, Atas processuais, vol. 5472, cc. nn., interrogatório do dia 22 de junho de 1626 (Niccoli, 2000:43-46).

${ }^{23}$ Bastiano, s.d.:480v . Em Sarti, 1999, falei dessa composição como de uma obra dos séculos XVI-XVII; Bastiano, ao invés, viveu na segunda metade do século XV e nas primeiras décadas do século XVI; suas obras foram impressas entre 1518 e 1546, cf. http:/www.sbn.it/opacsbn/opaclib (acesso: fevereiro 2012) e De Blasi, 1970.
} 
numerosos pratos que sabe cozinhar (Capatti e Montanari, 1999:274). Os autores (id.:276-277) lembraram, nessa perspectiva, também o Breve catalogo de gli inventori delle cose che si mangiano e beveno que um intelectual experiente, em contato com os ambientes da Reforma Protestante como foi Ortensio Lando, publicou junto ao seu Commentario delle più notabili $e$ mostruose cose d'Italia e d'altri luoghi que afirmava, mentindo, ser uma tradução da língua "aramaica". Apresentado como texto "achado em forma nova", mas na realidade escrito por ele, havia nesse catálogo uma lista de várias mulheres entre os inventores de pratos e comidas. Segundo Lando, de fato, "Libista, camponesa lombarda de Cernuschio, tinha sido a inventora, entre as outras coisas, de fazer ravioli enrolados na massa"; Macaria de Cremona foi a primeira a fazer a carne ao molho tártaro e tinha inventado uma comida feita com nozes chamada nosetto; outros pratos saborosos foram feito por Marina de Offlaga, Melibea de Minerbio e Meluzza da região de Como, "inventora de comer lasanhas, macarrão com alho, especiarias e queijo" e outras iguarias, entre as quais os pizzoccheri [um tipo de massa]; outros reconhecimentos iam à Camena de Piperno, Camilla Anconitana, Coccolina de Lucca e Calandrina de Pistoia - a primeira a cozinhar "tripas de bezerro, de boi, de porco e de cabrito" -, à Menina Brincesca, criadora da salsa verde; à Meridiana de Cesenna [sic], criadora de vários "molhos muitos saborosos", à Melina de Reggio, à Calidonia Brunella e outras ainda (Lando, 1994:126-128). Naturalmente não é fácil estabelecer que valor atribuir a afirmações feitas em textos complexos como o de Lando. Faccioli (1992:275) acha que o Catálogo esteja "corrompido pelo gosto da mistificação"; Capatti e Montanari (1999:276) destacam seu valor de brincadeira; Simonetta Adorni Braccesi e Simone Ragagli (2004) afirmam que no Comentário "a exaltação da comida veicula um triunfo cômico da corporalidade e está ligado ao tema do país de Cocanha, com possíveis sugestões de François Rabelais". Não se deve esquecer que Lando, em contato com as maiores intelectuais de seu tempo, foi autor de escritos que, 
Melhor o cozinheiro?

inserindo-se nas diatribes sobre os dois sexos, realçavam as capacidades das mulheres. Se, portanto, permanece em aberto a questão de como interpretar o reconhecimento, por parte de Lando, da contribuição ao progresso gastronômico dada pelas mulheres e até pelas camponesas, é interessante que uma versão remanejada do catálogo tenha sido inserida em um livro de "alta" cozinha como a Pratica e Scalcaria de Frugoli (1638).

Fontes totalmente diferentes confirmam, por outro lado, o papel nada periférico da inventiva feminina. É o caso, por exemplo, do receituário da Irmã Maria Vittoria della Verde (1988), coletado entre 1583 e 1607 com 170 receitas destinadas, segundo Muzzarelli (2003:72), não apenas do mosteiro, mas também do mundo de fora. Sabe-se, além disso, que as monjas preparavam iguarias que muitas vezes ultrapassavam as paredes do claustro: sempre em Bolonha, um manuscrito do século XVIII com 41 aquarelas, cada uma acompanhada de duas linhas de explicação, descrevia as "obras manuais" das monjas dos vários mosteiros da cidade, muitas das quais eram especialidades de comida. As canônicas regulares lateranenses do mosteiro de São Lourenço, por exemplo, "di Cottogne fan Gelo delicato, // Da Dame, e Cavaglieri aßai stimato" [de marmelos fazem geleia delicada, muito apreciada por Damas e Cavaleiros]; as monjas camaldolenses do mosteiro de Santa Cristina da Fondazza "fan Biscotti con muschio, ed acqua rosa, //Che non si può gustar la miglior cosa" [fazem Biscoitos com musgo e água de rosas, que coisa melhor não se pode saborear], e por aí vai, em um catálogo que dá água na boca (Fanti, 1972:49, 53). Certamente se trata de uma fonte tardia em relação àquelas analisadas até este parágrafo, mas vários estudos confirmam fluxos de bens e comidas de e para os mosteiros também nos séculos XVI e XVII - o Concílio de Trento (1543-1563), apesar de impor uma clausura mais rígida, não interrompeu totalmente esses fluxos. ${ }^{24} \mathrm{~A}$ cozinha dos conventos, por outro lado, é considerada por alguns estudiosos como uma

${ }^{24}$ Ex. Laven, 2004:146; Evangelisti, 2007:51, 123. 
espécie de trait d'union "entre os refeitórios popular-camponeses e aqueles da nobre aristocracia da cidade" (D’Ambrosio, 2011).

O receituário da Irmã Maria Vittoria, no entanto, permaneceu manuscrito, ao contrário de muitos outros receituários de grandes cozinheiros que, aliás, não só foram publicados, mas, em muitos casos, tiveram muitas edições. Os modos de comunicação e difusão da receita da cozinha feminina, por um lado, e da masculina, do outro, eram diferentes, na Itália como em outros países. Na Espanha,

junto a cocineros y textos consagrados come el de Montiño $^{25}$ conviven otros recetarios no profesionales conocidos como recetarios de mujeres, por ser las responsables de la alimentación familiar. Todos ellos se conservan manuscritos y no se dieron a la imprenta en la Edad Moderna (Moyano Andrés, 2010:24). ${ }^{26}$

A situação não parece diferente na França: aqui também os autores dos livros de cozinha publicados nos séculos XVI e XVII são homens (Hyman e Hyman, 1997). Porém não é assim em todos os lugares.

O mundo alemão

O primeiro livro de cozinha alemão impresso, cuja autora é uma mulher, remonta a 1597. Trata-se de Ein köstlich new Kochbuch, de Anna Wecker. Mulher do famoso médico Johann Jakob Wecker, Anna, em seu livro, cuidava da saúde dos seus

\footnotetext{
${ }^{25} \mathrm{O}$ receituário de Francisco Martínez Montiño, cozinheiro na corte de Filipe III, intitulado Arte de cocina, pastelería, bizcochería y conservería (Madrid, Luis Sánchez, 1611) constitui o receituário barroco espanhol mais importante.

${ }^{26}$ Agradeço Carmen Abad Zardoya por ter me enviado gentilmente uma cópia do rico catálogo que diz respeito à exposição relativa ao mundo da cozinha espanhola que houve em Madrid do dia 22 de dezembro de 2010 ao dia 13 de março de 2011 (veja http:/www.bne.es/es/Micrositios/Exposiciones/Cocina/, acesso: fevereiro de 2012).
} 
Melhor o cozinheiro?

leitores, oferecendo ao mesmo tempo receitas para preparações elaboradas, para a cozinha de todos os dias, para pratos rápidos, $e$ até indicações para as famílias mais pobres. ${ }^{27}$ Mesmo antes, entretanto, as mulheres na Alemanha, inclusive de classe alta, aventuraram-se na escritura de livros de cozinha, mesmo sem publicá-los. $\mathrm{O}$ mais antigo, atribuído a uma mão feminina, parece ser Das Kochbuch der Philippine Welser, que provavelmente remonta a 1545. O texto, manuscrito, pertenceu sem dúvida a Philippine, filha do patrício de Augusta Franz Welser e esposa do arquiduque Ferdinando II de Habsburgo (1557), mas provavelmente ela deve ter feito apenas um acréscimo final. ${ }^{28}$ Talvez, originalmente, o livro tivesse sido dado a Philippine pela mãe (Peter, 2008:53); pensado por uma família de nobres da cidade, segundo Dürrschmid (2002:cap. 3, pp.8-9) provavelmente se revelou inadequado para a vida elegante de Philippine após seu casamento com o arquiduque, principalmente quando acabou a obrigação, para os dois, de mantê-lo em segredo (imposto inicialmente por causa da diferença social entre os noivos: os Welser eram uma família de banqueiros e comerciantes). O castelo de Ambras, nas proximidades de Innsbruck, onde viviam, tornouse o centro de uma vida social luxuosa na qual desempenhavam um papel importante os banquetes com pratos, vinhos, vasilhas, toalhas e talheres extremamente refinados. Philippine seguia com atenção a cozinha, redigindo diariamente o cardápio. Nascida em uma família que se enriqueceu também com o comércio de especiarias e envolvida na colonização da América do Sul ${ }^{29}$, junto

\footnotetext{
${ }^{27}$ Wecker 1598. Cf. a respeito Dürrschmid, 2002:16; Peter, 2008:56; Notaker, 2010:7, 247.

${ }^{28}$ Koch und Arzneibuch der Philippine Welser, ms, sec. XVI, Innsbruck, Schloß Ambras., Inv. n. PA 1473; Kochbuch der Philippine Welser, ms, sec. XVI, Innsbruck, Schloß Ambras., Inv. n. PA 1474, sobre o qual cf. Dürrschmid, 2002:8-9. O texto foi publicado sob a organização de Gerold Hayer, Leipzig, Ed. Leipzig, 1983.

${ }^{29}$ Os Welser obtiveram de Carlos V, a quem tinham garantido grandes financiamentos, concessões importantes para a exploração da Venezuela; em
} 
com a irmã Katharina von Loxan experimentou novos pratos, preparados inclusive com os produtos que chegavam do Novo Mundo, e juntou novas receitas.

Ao contrário, outro texto manuscrito quase da mesma época, Das Kochbuch der Sabina Welserin (1553), foi provavelmente redigido na sua totalidade pela mulher a quem é atribuído, aquela Sabina Welser ainda não identificada com exatidão e que, juntamente, com Philippine, além da paixão pela cozinha, compartilhava o fato de pertencer à família Welser de Augusta. ${ }^{30}$ Se por um lado, portanto, no mundo alemão já no século XVI havia (precocemente) autoras de livros de cozinha, por outro os autores masculinos que, naquela época, escreviam Kochbücher, não se dirigiam só aos homens, mas também às mulheres, como se depreende olhando os títulos dos volumes de Balthasar Staindl von Dillingen (Mannen und Frawnpersonen) ${ }^{31}$ ou de Marx Rumpolt (Allen Menschen, hohes und nidriges Standes, Weibs und Manns Personen). ${ }^{32}$ Por outro lado, também nos

1541, contudo, foram privados da colônia por causa dos conflitos com a Espanha.

${ }^{30}$ Das Kochbuch der Sabina Welserin, Augsburger Staats- und Stadtbibliothek, assinatura $4^{\circ}$ Cod. 137. O texto é publicado por Hugo Stopp org. (Heidelberg, C. Winter, 1980); para o texto cf. http://www.uni-giessen.de/gloning/tx/sawe.htm acesso: fevereiro de 2012. Cf. a respeito Dürrschmid(2002:10).

${ }^{31}$ Ein künstlichs und nutzlichs Kochbuch, vormahlens nie so leycht, Mannen und Frawnpersonen, von jnen selbst zulernen..., Augsburg, Stayner, 1544. Cf. a respeito Notaker (2010:231) Peter (2008:53-54) fala de uma edição de 1545; Dürrschmid (2002: 11) de uma edição de 1569 com o título um pouco diferente: há um sehr [muito]) a mais: EJn sehr Künstlichs und nutzlichs Kochbu:och vormals nye in so leicht/ Mannen unnd Frawenpersonen von jnen selbst zu lernen in Truck verfast vnd außgangen ist Artlich in acht Bu:echer getheilt sampt etlichen fast nutzen bewehrten Haußnotturfften oder künsten. Auch wie man Essig macht und Wein gu:ot behelt (veja http://www.uni-giessen.de/gloning/tx/staind69.htm acesso: fevereiro de 2012).

${ }^{32}$ Notaker (2010:242) indica uma edição de 1576 do texto (Frankfurt am Main, Iohnann Feyerabend for Sigmund Feyerabend); Peter (2008:54) afirma que a obra foi publicada pela primeira vez em Mainz em 1581; o título completo da edição que apareceu em Frankfurt em 1581 é Ein new Kochbuch, Das ist: Ein 
Melhor o cozinheiro?

séculos seguintes as mulheres que se aventuraram em escrever livros de receitas foram numerosas ${ }^{33}$, confirmando o fato de que na área alemã a cozinha tinha um caráter marcadamente feminino. Maria Sophia Schellhammer - filha do famoso médico Hermann Conring, mulher do naturalista G. Ch. Schellhammer, e autora, além de uma tradução de Boccaccio, de dois livros de cozinha (respectivamente em 1692 e 1699)-, no primeiro dos dois se dirigiu diretamente às "Leserinnen", isto é, às leitoras, porque, explicou, esperava que fossem sobretudo as mulheres a lerem seu volume. $^{34}$ No entanto, também autores masculinos se dirigiam exclusivamente às mulheres. ${ }^{35}$ Peter (2008:9), não por acaso, sustentou que as mulheres alemãs forjaram a consciência pública da cozinha antes e com maior sucesso do que as mulheres de outros países, graças particularmente ao empenho como autoras de livros nessa matéria, empenho que pode ser remontado até os textos dietéticos de Ildegarda de Bingen. De modo especular, as habilidades na cozinha eram talvez importantes na definição da identidade feminina: uma pesquisa sobre uma amostra de

Gründtliche Beschreibung, wie man recht vnd wol, nicht allein von vierfüssigen, heymischen unnd wilden Thieren, sondern auch von mancherley Vögel und Federwildpret, darzu von allem grünen vnd dürren Fischwerck, allerley Speiß, als gesotten, gebraten, gebacken, Presolen, Carbonaden, mancherley Pasteten und Füllwerck, Gallrat, \&c. auff Teutsche, Vngerische, Hispanische, Italianische und Frantzösische weiß, kochen vnd zubereiten solle. Auch wie allerley Gemüß, Obß, Salsen, Senff, Confect und Latwergen, zuzurichten seye. Auch ist darinnen zu vernemmen, wie man herrliche grosse Bancketen, sampt gemeinen Gastereyen, ordentlich anrichten und bestellen soll. Allen Menschen, hohes und nidriges Standes, Weibs und Manns Personen zu nut jetzundt zum ersten in Druck gegeben, dergleichen vor nie ist außgegangen. Sampt einem gründtlichen Bericht, wie man alle Wein vor allen zufällen bewaren, die bresthafften widerbringen, Kräutter und andere Wein, Bier, Essig, und alle andere Getränck, machen und bereiten soll, daß sie natürlich, vnd allen Menschen vnschädtlich, zu trincken seindt. Dürrschmid (2002:12-13) cita uma edição de 1587. Pessoalmente vi a edição Franckfort am Mayn, Johann Saurn, 1604.

${ }^{33}$ Cf. Dürrschmid (2002).

${ }^{34}$ Schellhammer, 1732:2r.

${ }^{35}$ Por ex. Reichenbach, 1794. 
inventários alemães do século XVII revela não só que as mulheres possuíam mais objetos relacionados com a preparação da comida do que os homens, mas também que mulheres de classe social bastante baixa possuíam instrumentos específicos para preparações um tanto elaboradas (Ogilvie, Küpker, Maegraith, 2009).

\section{A Inglaterra ${ }^{36}$}

A análise dos textos de cozinha e os resultados dos estudos conduzidos até agora indicam que, também na Inglaterra, as mulheres desempenharam um papel importante, embora talvez em uma primeira fase - um pouco menos acentuado do que no mundo alemão. Desse ponto de vista, é significativo que, na GrãBretanha dos séculos XVI e XVII, fossem publicados textos classificáveis segundo o gênero literário das "coletâneas de segredos", escritos ou atribuídos a mulheres, direcionados às damas para instruí-las nas artes necessárias a fim de realizar de modo melhor os deveres associados à sua posição, e contendo também receitas de cozinha (Flandrin, 1997:441-442; Kavey, 2007). Ao invés disso, os Livros de segredos ou Livros de receitas italianos, mais do que conhecimentos ligados à esfera doméstica, propunham um saber elaborado no mundo (masculino) das oficinas dos artesãos. Eram escritos prevalentemente por homens - apenas um, entre os publicados, apresentava-se como obra de uma mulher, Isabella Cortese (1561), mas não há certeza de que fosse mesmo assim (Leong e Ranking, 2011:17). E eles se dirigiam principalmente a homens, embora uma das categorias na qual o gênero pode ser dividido, aquela relativa à preparação de cosméticos e perfumes, a partir da metade do século XVI dirigiu-se cada vez mais também a um público feminino (Storey, 2011). E se nos textos ingleses havia também receitas de preparações culinárias, o mesmo não acontecia naqueles italianos (Cavallo,

${ }^{36}$ Por simplicidade usarei "Inglaterra" e "Grã-Bretanha" como sinônimos e em relação a todo o período considerado aqui, seguindo o uso comum da língua italiana, embora tenha consciência de que este uso não é rigorosamente correto. 
Melhor o cozinheiro?

2011:192): os textos italianos (e franceses) forneciam, quando muito, como lembra Flandrin (1997:441-442), "receitas de geleias, de conservas, de xaropes" e de outras especialidades açucaradas, associadas na época a tratamentos médicos e terapias, mas não verdadeiras receitas de cozinha. Isso, todavia, não significa que, nos textos ingleses, as preparações confeiteiras não fossem importantes. Ao contrário, tinham um papel importantíssimo. Por exemplo, no The treasurie of commodious conceits \& hidden secrets, and may be called, The huswives closet (London, Richard Jones, 1573), "virtually all of the recipes for edibles are for sweets" (Holman, 2002:1). Segundo Lehmann (1999:126), a feminização dos livros de cozinha, elemento característico do cenário inglês, entrelaçou-se com a ascensão e a transformação do uso do açúcar, inicialmente utilizado como fármaco e depois como ingrediente para a confeitaria e a cozinha. A centralidade das complexas "invenções" (conceits) feitas de açúcar, marzipã e outras massas, refletia, entre outras coisas, segundo Spiller (2008:XIV-XVI), uma ideia de natureza controlável pela arte e da arte como forma de conhecimento que até antecipava a concepção seiscentista da natureza como mina de segredos que podiam ser descobertos pela ciência e pela filosofia natural. Nesse sentido, os livros de segredos, em relação aos quais as mulheres desempenharam um papel principal (como inspiradoras, leitoras e autoras), participavam, segundo ele, das transformações dos modos de conceber o saber que se traduziriam no desenvolvimento da nova ciência experimental.

The treasurie of commodious conceits \& hidden secrets, destinado a ser publicado muitas e muitas vezes em versões ampliadas e revistas, apresentava-se como livro escrito para mulheres e principalmente direcionado a elas, mas não exclusivamente. ${ }^{37}$ Não só isso: o poeta e tradutor John Partridge,

\footnotetext{
${ }^{37}$ No título extremamente longo da primeira edição do volume lia-se também: "necessarie for the profitable use of all estates both men and women" [necessário para o uso proveitoso de todas as posições sociais, mulheres e homens; tradução da revisora] (Holman, 2002:2).
} 
apresentado como autor do livro (Kavey, 2007:179; Holman, 2002), afirmava que escreveu o volume a pedido de uma senhora com quem estava ligado por vínculos de amizade e que publicou receitas médicas e de cozinha, "segredos" até então nunca divulgados, que ele recolhera por interesse seu e de seus amigos. Onde os havia coletados? Algumas receitas provêm do volume De' secreti del reverendo donno Alessio Piemontese (Venetia, per Sigismondo Bordogna, 1555), obra geralmente atribuída ao polígrafo italiano Girolamo Ruscelli que teve um sucesso extraordinário por um longo período em toda Europa, onde foi traduzida em muitíssimas línguas, entre as quais o inglês (The Secrets of Alexis. London, John Wright, 1558) (Spiller, 2008:14). Parece provável, no entanto, que Partridge coletara também receitas de textos manuscritos e das quais se utilizavam para uso pessoal, as mulheres da sua família, os seus amigos (Holman, 2002:1).

Por outro lado, muitos livros de receitas ingleses baseavamse em coleções manuscritas das famílias nobres, e das damas em particular; e se, em uma primeira fase, os nomes das damas permaneceram desconhecidos, nos anos trinta do século XVII coleções inteiras ou preparações individuais foram associadas a nomes de mulheres nobres, fato que demonstra como as atividades de cozinha eram consideradas respeitáveis. Segundo Lehmann (1999:126), nisso tudo desempenhava novamente um papel importante também o açúcar, cujo prestígio teria inicialmente envolvido inclusive todas as atividades que implicavam seu uso. Seja como for, a coleção de receitas de cozinha envolveu também homens de classe social alta como Sir Kenelm Digby, personagem eminente da corte dos Stuart, médico e cientista, além de militar e corsário, ou também Lord Ruthven, químico (id.ib.; Mennell, 1987:130-132). Mas o mecanismo funcionava também em sentido inverso: o fato que em The treasurie of commodities conceits and hidden secrets se afirme ter uma nobre mulher solicitado sua publicação, significa que as mulheres, pelo menos de uma certa classe, tinham autoridade suficiente para fazer publicar um livro de segredos. A análise dos 
Melhor o cozinheiro?

textos ingleses evidencia que as mulheres tinham bastante autoridade para ser apresentadas, por causa da sua posição social e das suas competências, também como asseguradoras do valor $e$ da utilidade do saber veiculado, bem como da legitimidade da publicação de conhecimentos até então "secretos". É o caso de The Widowes treasure, livro de medicina, veterinária e cozinha também atribuído a John Partridge (Holman, 2002; Kavey, 2007:95 e passim $^{38}$ que apresentava um conhecimento brotado da reconhecida habilidade de cura de uma nobre mulher (Kavey 2007:4-8;104-106).

Igualmente, volumes como The Good Huswifes Jewell (1585), de Thomas Dawson ${ }^{39}$, e The English Hus-wife (1615), de Gervase Markham, baseavam-se em coleções de receitas manuscritas que pertenceram a mulheres nobres (Lehmann, 1999:126; Best, 2003:XVII-XVIII). Tratava-se de manuais de gestão doméstica mais do que livros de segredos, embora tenha que ser realçado que, entre os séculos XVI e XVII, a fronteira entre gêneros diferentes era bastante fugaz, e isso também por causa das numerosas reimpressões e remanejamentos de textos que forneciam receitas de vários tipos, e de cópias e contaminações entre uns e outros (Holman, 2002; Albala, 2003:168; Spiller, 2008:XI). Os livros de Dawson e Markham continham discussões de caráter médico, indicações para curar as doenças mais comuns, receitas de cozinha, informações sobre o processamento do leite, sobre a preparação da cerveja, sobre os modos de conservar os alimentos, etc. O livro de Gervase Markham apresentava-se como texto que tratava de todas as qualidades que uma mulher devia ter para ser perfeita, isto é, competências nos seguintes âmbitos e nos

\footnotetext{
38 The widowes treasure, plentifully furnished with sundry precious and approved secretes in physicke and chirurgery for the health and pleasure of mankinde: hereunto are adjoyned sundry pretie practises and conclusions of cookerie: with many profitable and holesome medicines for sundrie diseases in cattell, London, by Robert Walde-Grave for Edward White, 1585 (veja Holman, 2002:8).

${ }^{39}$ Algumas informações a respeito, no site da British Library: http:/www.bl.uk/learning/langlit/texts/cook/1500s2/1550s2.html (acesso: fevereiro de 2012).
} 
seguintes sujeitos: medicina, cozinha, preparação de doces [banquetting stuff], destilação, perfumes, vinhos, lã, cânhamo, linho, roupas, tingimento dos tecidos, processamento do leite, manteiga, queijo, preparação do malte, produção da cerveja, preparação do pão (Markham, 2003; Mennell, 1987:125-130).

Livros desse tipo, direcionados a donas de casa que seguiam em primeira pessoa todos os aspectos do seu ménage, que continham receitas de cozinha bastante simples e também, muitas vezes, receitas médicas - continuaram a ser impressos também na segunda metade dos séculos XVII e XVIII. Quanto aos cozinheiros profissionais, começaram a publicar apenas em meados do século XVII e deram início a uma produção semelhante aos livros de cozinha franceses e italianos, quer dizer, volumes concentrados só na preparação de comida refinada e direcionados, principalmente, a outros cozinheiros. ${ }^{40}$ Além disso, naquela época começaram a ser publicadas também traduções de livros de cozinha italianos e franceses. ${ }^{41} \mathrm{E}$, a partir do século XVII, os cozinheiros estrangeiros, particularmente os franceses, tornaram-se de moda no topo da escala social, embora em círculos muito pequenos (em particular, no início do século XVIII, entre a élite whig). Não por acaso, os cozinheiros ingleses, nas primeiras décadas do século XVIII, procuraram apresentar-se como artistas para vencer a

\footnotetext{
${ }^{40}$ Mennell, 1987:130-132; Lehmann, 1999:127. Entre os textos ingleses cf. por ex. The Accomplish't Cook, or the Art and Mystery of Cookery de Robert May (1660); The Whole Body of Cookery Dissected de William Rabisha (1661); Royal Cookery; or the Complete Court Book de Patrick Lamb. Mennell fala a respeito de comida "da corte"; em todo caso, eram sobretudo variações na cozinha inglesa tradicional que se distanciavam menos da cozinha doméstica como no caso da haute cuisine francesa.

${ }^{41}$ Por ex. Epulario, or, the Italian Banquet: wherein is shewed the maner how to dresse all kinds of Flesh, Foules or Fishes Translated out of Italian. London, Printed by A. I. [Abel Jeffes] for William Barley, 1598 (tradução do Epulario de Giovanni de' Rosselli, publicado pela primeira vez em Veneza em 1517 e depois reimpresso muitas vezes; retomava o receituário do séc. XV do Mestre Martino de Como); La Varenne, Pierre François. The French Cook Englished by J D G. London, 1653. Sobre as traduções dos textos franceses cf. Mennell, 1987:133.
} 
Melhor o cozinheiro?

concorrência dos cozinheiros franceses. Não faltaram polêmicas contra os cozinheiros que estavam do outro lado do Canal da Mancha, acusados - entre outras coisas - de recorrer excessivamente a artifícios (Mennell, 1987:133-137; Lehmann, 1999:127-130). Em relação à cronologia dessa paixão pela haute cuisine, enquanto o velho estudo de Hecht (1980:43) sugere que foi crescendo durante o século XVIII, o mais recente de Lehmann (1999:127, 130-132) sustenta que ela se esgotou bastante rapidamente e que, em meados do século XVIII, era objeto de desaprovação, inclusive por receio de uma excessiva atenção para os prazeres dos sentidos; na segunda metade do século, além disso, o medo da concorrência francesa no plano cultural $e$ gastronômico teria diminuído. Segundo Mennell (1987:142, 286), o século XVIII foi testemunho da afirmação da cozinha doméstica e, substancialmente, a época de ouro da cozinha "rústica" inglesa.

O filão dos textos escritos por cozinheiros (homens) profissionais, que não era muito rico, esgotou-se de fato por volta de 1730. Os manuais de instrução tais como "a dona da casa do interior" eram muito mais numerosos e alguns tiveram grande sucesso, como The Queen-Like Closet, de Hannah Wolley, publicado em $1670 .{ }^{42}$ Nem sempre as autoras eram mulheres. A partir de meados do século XVIII, no entanto, a produção de textos de cozinha foi dominada por autoras (inglesas) que propunham pratos simples e nutritivos; mulheres que escreviam para outras mulheres, geralmente para donas da casa ou empregadas que cozinhavam nas casas da burguesia e da pequena e média nobreza. ${ }^{43}$ Em 1747, Hannah Glasse, na introdução do seu volume The Art of Cookery made Plain and Easy, afirmava que a finalidade de seu livro, em sua opinião nunca tentada antes, era

\footnotetext{
${ }^{42}$ Wolley, Hannah. The Queen-like Closet; or, rich cabinet; stored with all manner of rare receipts for preserving, candying, and cookery. Very pleasant and beneficial to all ingenious persons of the female sex. London, printed for $\mathrm{R}$. Lowndes at the White Lion in Duck-Lane, near West-Smithfield, 1670.

43 Mennell, 1987:130-133, 142-146, 288; Davidson, 1982:45-57; Weatherill, 1988:145-150.
} 
instruir "the Servants" [os criados]; pelo fato de se dirigir à "lower sort" [classe baixa], seu estilo não seria alto e refinado, portanto muito diferente daquele usado pelos grandes cozinheiros, incompreensível para as moças pobres às quais ela se dirigia. Não faltavam, por sua vez, acentos polêmicos contra os cozinheiros franceses e sua cozinha desnecessariamente cara. A polêmica contra os cozinheiros franceses apreciados pelos gentlemen estava relacionada com uma questão de gênero: Hannah Glasse duvidava poder conseguir a estima desses senhores (homens), mas declarava que teria sido feliz caso a tivesse obtido das pessoas do seu mesmo sexo. Na sua opinião, "every Servant who can but read" [qualquer criada que pudesse ler], graças ao seu livro, poderia se tornar uma cozinheira razoável, enquanto as empregadas domésticas que tinham algum conhecimento de cozinha se tornariam ótimas cozinheiras. Ao perseguir o objetivo de melhorar as servas, Hannah Glasse tinha em mente também suas patroas. Visava, de fato, "improve the Servants, and save the Ladies a great deal of Trouble" [aprimorar os criadas, e evitar muitos problemas às senhoras], afirmações que deixam entender que as damas, pelo menos até aquele momento, cuidavam pessoalmente da cozinha, pelo menos para instruir o pessoal de serviço (Glasse, 1774:I-VI). Parece, contudo, que as cozinheiras não conseguiam ser estimadas e tampouco pagas como os cozinheiros franceses (Hecht, 1980:65; Holman, 2002:131-132). Por outro lado, eram mulheres em uma sociedade organizada com base em grandes assimetrias de gênero. A ênfase, além disso, era colocada em uma cozinha nutritiva e barata. Holman lembra que, ao longo do século, havia cada vez mais a expectativa de que as nobres mulheres supervisionassem a preparação da comida a ser distribuída aos pobres no lugar da haute cuisine francesa. E, provavelmente, se deve também a essa ênfase do papel assistencial das damas o reaparecimento, nos livros de cozinha, de remédios contra as doenças, desaparecidos nos textos dos cozinheiros profissionais, naquele de Glasse e de outras autoras contemporâneas (Holman, 2002:131-132). 
Melhor o cozinheiro?

\section{Gender, Class, and Nation(ality): para uma geografia europeia}

Em países como França e Itália, a dimensão de gênero estava associada à posição social, no sentido de que a cozinha de elite era dominada por cozinheiros homens, enquanto no resto das famílias nas quais alguém preparava a comida, a cozinha estava sob o cuidado das mulheres. Na Inglaterra, as alternativas entre cozinha masculina e feminina de um lado e, de outro, entre cozinha de elite e cozinha "comum" se conjugaram, entre os séculos XVII e XVIII, também com a alternativa entre cozinha à francesa e cozinha inglesa. A grande maioria da população, com efeito, comia à inglesa, alimentos preparados por mãos femininas: mãos das mulheres de família ou também de empregadas domésticas e cozinheiras. A preparação da comida era considerada uma tarefa feminina e esperava-se uma certa competência na cozinha também por parte das senhoras de nível social médio e médio-alto (Overton et alii, 2004:80; Flather, 2011). No topo da sociedade, ao invés disso, comia-se à francesa e os cozinheiros eram domésticos de sexo masculino, como prescrevia a tradição do outro lado da Mancha.

Seja como for, no século XVIII, mesmo com as flutuações das modas acenadas acima, as moradias que seguiam a moda gálica eram uma exígua minoria. Jonathan Swift (1745:36-37), nas suas cáusticas e cortantes Directions to the Servants escritas talvez em 1731 e publicadas póstumas, no capítulo dedicado aos cozinheiros dirigia-se a uma cozinheira de sexo feminino argumentando de modo evidente o entrelaçamento complexo entre class, gender and nationality [classe, gênero $e$ nacionalidade], como se diria com uma linguagem atual, que caracterizava o modo das cozinhas inglesas:

Embora não ignore que há muito tempo, desde que era costume entre as pessoas de estirpe manter cozinheiros, $e$ geralmente provenientes da nação francesa; e ainda por que meu tratado é direcionado principalmente aos 
cavaleiros, squires e nobres, tanto do campo quanto da cidade, devo solicitá-la, Sra. Cook, como mulher: contudo, grande parte do que eu pretendo deve servir a ambos os sexos. ${ }^{44}$

Mas se apenas uma pequena elite seguia a cozinha francesa no século XVIII, entre o final das guerras napoleônicas e a metade do século XIX, ela teria maior sucesso: derrotado Bonaparte no campo, camadas mais amplas da sociedade inglesa seriam conquistadas pelos franceses na mesa (Mennell, 1987:137, 185, 287-305). Ao mesmo tempo, contudo, a alternativa entre cozinha francesa entendida como arte e a cozinha inglesa entendida como gestão prudente de um budget foi se aprofundando (Holman, 2002:132).

Alguns estudiosos veem no fato de, em algumas casas inglesas abastadas, a preparação da comida ser confiada totalmente às servas, o sinal de uma piora da consideração atribuída a essas atividades (Overton et alii, 2004:80). Voltarei a esse tema mais adiante. Aqui gostaria de ressaltar que na Inglaterra, assim como no mundo alemão, o trabalho na cozinha parece ser considerado uma prática ancilar em menor grau do que na França, onde a cozinha, em todo caso, era refinada e apreciada. Parece que as damas $e$ as daminhas francesas de classe não cuidavam dela, pelo menos em primeira pessoa. E na Itália a situação parece semelhante (Flandrin 1996:441-442). Não "deve a boa mãe de família recusar, com desdenho, colocar, às vezes, suas mãos à obra", explicava, por exemplo, Torquato Tasso (1969, 1583:543) no final do século XVI. Mas "não nas cozinhas ou em outras coisas sórdidas que podem embrutecer o corpo", apressava-

\footnotetext{
44 "Although I am not ignorant that it hath been a long Time, since the Custom been among People of Quality to keep Men Cooks, and generally of the French Nation; yet because my Treatise is chiefly calculated for the general Run of Knights, Squires, and Gentlemen both in Town and Country, I shall therefore apply myself to you, Mrs. Cook, as a Woman: However, a great Part of what I intend may serve for either Sex".
} 
Melhor o cozinheiro?

se a acrescentar. ${ }^{45}$ "Fica bem para toda mulher saber cozinhar", escrevera muito tempo antes Agnolo Pandofini (1360-1446). Logo, porém, fez uma retificação: "Não que a mulher cozinhe: mas comande, ensine, e mostre às servas não tão instruídas, [como] fazer todas as coisas excelentes, e as melhores comidas, que serão exigidas" quando não estivessem presentes em casa cozinheiros profissionais, como acontecia por ocasião da organização de banquetes (apud Capatti, Montanari, 1999:276).

Ludovico Dolce (1622:15) sustentou que precisava ensinar às moças "o modo de cozinhar e de pôr em ordem as comidas". Ele esperava que os pratos fossem na sua maioria "cuidados $e$ administrados" pelas mulheres da casa, porque "são cada vez mais apreciadas por nós aquelas comidas preparadas pelas mãos das nossas irmãs, ou mulheres, ou filhas [...] que não são as outras, que são feitas pelas servas". Contudo, parecia estar ciente de que se tratava de uma batalha difícil, se não perdida: "sei bem que algumas Senhoras delicadas vão zombar de mim por colocar no cuidado da cozinha suas filhas". Alessandro Piccolomini (1575:547) achava que a mãe de família tivesse que designar uma serva para a cozinha, uma para os quartos e uma para realizar, no resto da casa, todas as tarefas apropriadas a empregadas domésticas de sexo feminino, como o tratamento de lãs e linhos. Portanto, não considerava a hipótese de cuidar da cozinha em primeira pessoa. Por sua parte, Giacomo Lanteri (1560:169), falando dos deveres de uma mãe de família de alta linhagem $e$ explicando as tarefas das serviçais femininas, não tratava da preparação da comida, limitando-se a dizer que uma mulher idosa (a "governante") tinha que dispor das chaves da despensa onde se guardavam as coisas da mesa. Claro que não faltavam exemplos em sentido contrário. O médico bolonhês Leonardo Fioravanti (1517-1588), além de polemizar contra os cozinheiros e suas

\footnotetext{
${ }^{45}$ A ideia de que as cozinhas fossem lugares sujos estava muito enraizada. Fala, por ex., de "servitij sordidi delle cucine" [serviços sórdidos das cozinhas"] Menochio, 1675:13.
} 
comidas artificiosas, prejudiciais para a saúde, afirmava que todas as mulheres tinham que saber cozinhar e também as nobres não deviam desdenhar a preparação do pão (Fioravanti, 1660:42-47, 488-489). Com uma análise mais profunda, no entanto, suas afirmações sobre os deveres das mulheres na cozinha resultavam ser uma cópia aproximada de um texto mais antigo, as Cartas de Antonio, de Guevara (1555:350-351), publicadas em espanhol e em seguida traduzidas em italiano. Certamente, é significativo que Fioravanti as considerasse dignas de ser copiadas. Ele também, no entanto, na esteira de Guevara, protegeu-se, como fizera Dolce, de possíveis objeções por parte dos leitores e das leitoras. No geral, em suma, o panorama italiano parecia muito diferente daquele anglo-saxônico e alemão. Como explicar, então, essa (presumida) diferença entre mundo inglês e alemão, de um lado, e o mundo ítalo-francês do outro?

Talvez seja possível levantar a hipótese de que estivesse relacionada com a persistência, na Europa neolatina, de tradições de origem romana antiquíssimas. De acordo com as afirmações de Tito Lívio e Plutarco, no tratado de paz entre os romanos e os sabinos que se seguiu ao "rapto das sabinas", os esposos das moças raptadas comprometeram-se em não lhes impor trabalhos humilhantes, como moer o grão e cozinhar. Portanto, esses trabalhos deveriam ser feitos por escravos. Em seguida, a preparação da comida teria sido reavaliada: em particular, depois da guerra de Ásia contra Antíoco (186 a.C.), nos banquetes afirmou-se um luxo cada vez maior. Então, afirma Tito Lívio, "os cozinheiros, que para nossos antepassados eram só os últimos entre os escravos, e os menos úteis, começaram a ficar muito caros, e uma profissão baixa foi considerada uma arte". ${ }^{46}$ Primeiro desprezado, depois apreciado, no topo da sociedade romana o trabalho na cozinha parecia ser, em todo caso, uma atividade de escravidão e dos homens. De modo semelhante, na França e na

${ }^{46}$ Tito Lívio, Ab urbe condita, XXXIX, 6, cit. em Deonna, Renard, 1994:62, nota 52. Cf. também p. 45. 
Melhor o cozinheiro?

Itália, durante a Idade moderna, no topo da escala social a preparação e a arrumação da comida eram reservadas aos empregados homens.

Mas, sem procurar raízes tão distantes, talvez seja possível encontrar razões mais contingentes para explicar as diferenças encontradas. Mestre Martino de Como, autor quatrocentista de um texto de cozinha destinado a exercer uma grande influência, apresentava-se como ex-cozinheiro do "Reverendíssimo Monsenhor Camorlengo et Patriarcha de Aquileia" (Faccioli, 1992:129-131); Bartolomeo Scappi, cuja Opera é considerada o epítome da gastronomia do Renascimento, foi cozinheiro secreto dos papas (Di Schino, Luccichenti, 2007). Sem dúvida a corte pontifícia e as cortes cardinalícias desempenharam um papel importante enquanto modelos de organização, e eram formadas por pessoas de sexo masculino, tendo no ápice homens solteiros. ${ }^{47}$

Além disso, na Itália e na França, a cozinha desempenhava um papel "público" em maior medida do que na Inglaterra, embora no contexto inglês a hospitalidade $e$ as oferendas de alimentos fossem elementos importantes na construção de relações sociais e de patronage com valores também políticos (Heal, 2008). Na Grã-Bretanha, de fato, principalmente depois das revoluções seiscentistas, a corte não tinha nenhum poder $e$ nenhum papel de arbiter elegantiarum comparáveis aos das cortes refinadas italianas do Renascimento, ou que a luxuosa corte francesa possuía nos séculos XVII e XVIII.

Nesses contextos, de fato, os banquetes tinham a função "pública" e "política" de ostentar e consolidar o poder do príncipe ou do rei. Em outras palavras, o poder expressava-se e reforçavase também graças a estátuas de manteiga e fontes de vinho, e a nobreza era solicitada a engajar-se em uma competição que era combatida também graças aos banquetes com cem pratos $e$ invenções mirabolantes (Elias, 1969). Ao invés disso, na Inglaterra,

${ }^{47}$ Fragnito, 1988; Fragnito, 1991; Sarti, 1994a:51-91. 
principalmente no século XVIII, a cozinha não tinha um papel semelhante ao de um campo de jogo para a competição social.

Em parte, justamente pela menor capacidade de atração da corte, a nobreza inglesa continuava a viver, pelo menos durante alguns meses do ano, nas residências do interior. Tudo isso juntamente com o fato de que na Inglaterra havia uma pequena nobreza (gentry) cujos limites inferiores eram difíceis de ser identificados - contribuía provavelmente para explicar por que a cozinha britânica tivesse, pelo que é possível avaliar, características domésticas mais acentuadas (no sentido atual da palavra ${ }^{48}$ ) do que a francesa e a italiana, nas quais desempenhavam um papel mais importante cozinheiros profissionais $e$ outras pessoas altamente qualificadas, envolvidas na preparação de banquetes carregados, justamente, de importantes valores públicos e políticos (Mennell, 1987:159-194). Se o caso de Philippine Welser, analisado acima, parece constituir um exemplo interessante de cozinha "de corte", com valores públicos altíssimos, seguida em primeira pessoa por uma "dona de casa" de alto nível, Peter (2008:71), realça as características domésticas também na cozinha alemã, que teriam ocasionado uma valorização especial das cozinheiras e o amplo envolvimento das mulheres na redação dos livros de cozinha.

A referência a esse último aspecto, enfim, não deve nos fazer esquecer de que o fato de mulheres alemãs e inglesas, mas não italianas e francesas, publicarem livros de cozinha entre os séculos XVI e XVIII, tornando assim acessível a um público mais amplo seu saber gastronômico, tornou-se possível porque os níveis de alfabetização feminina eram significativamente maiores nos primeiros dois países do que nos segundos. ${ }^{49}$

\footnotetext{
${ }^{48}$ Os grandes cozinheiros, na sociedade do Antigo Regime, eram considerados membros do pessoal doméstico das casas em que serviam; tratava-se de casas com um papel "público" importante.

${ }^{49}$ Com base nos dados disponíveis, sintetizados por Delpiano (2007:51-52), no final do século XVIII, nos centros urbanos do Norte da Itália, no momento do casamento havia $21 \%$ de mulheres alfabetizadas, aproximadamente $5 \%$ na zona
} 


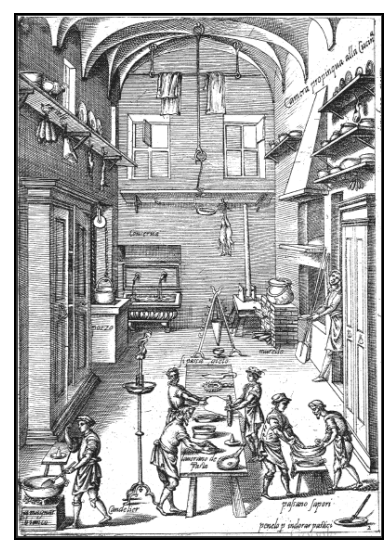

Fig. 1. Bartolomeo Scappi, Opera (1570)

Fonte: books.google.it

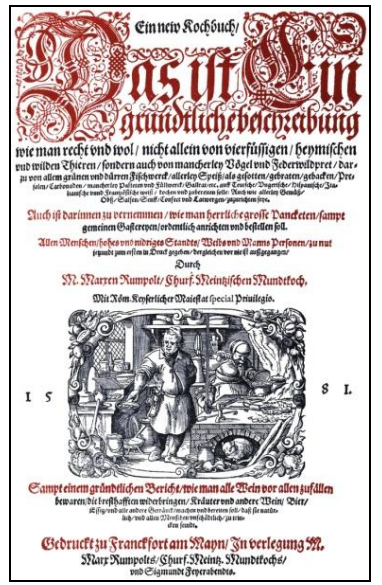

Fig. 2. Marx Rumpolt, Ein new Kochbuch (ed. 1581) Fonte: http://upload.wikimedia.org/wik ipedia/commons/1/19/Ein_new Kochbuch\%2C_Marxen Rum polt\%2C_1581\%2C_Einleitung .jpg

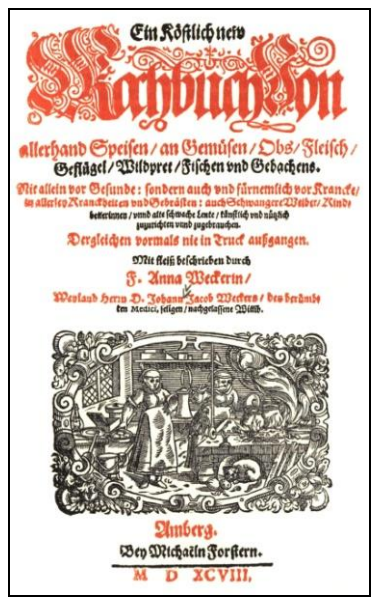

Fig. 3. Anna Wecker, Ein köstlich new Kochbuch (ed. 1598) Fonte: http://upload.wikimedia.org/wikip edia/commons/2/27/Ein_k\%C3\% B6stlich_new_Kochbuch\%2C_15 98\%2C_Anna_Weckerin\%2C_Ei nleitung.jpg

rural; na França setecentista, estima-se que a percentagem fosse de $27 \%$; na Inglaterra, de $40 \%$. 


\section{Mulheres e homens na cozinha: iconografia (algumas notas)}

Como mencionado, o primeiro livro alemão publicado por uma mulher é de Anna Wecker. A folha de rosto da edição mais antiga que eu pude ver, de 1598 (a primeira é de 1597), apresenta a imagem de uma cozinha na qual há duas mulheres que estão cozinhando (Fig. 3). A imagem, significativamente, retoma aquela que apareceu na folha de rosto do texto de cozinha alemã mais importante da época, Ein new Kochbuch, de Marx Rumpoldt, na edição de Frankfurt de 1581 (a mais antiga da qual pude ver a folha de rosto é de 1576 , como foi dito). ${ }^{50}$ No caso do texto de Wecker, o cozinheiro presente no volume de Rumpoldt é substituído por uma mulher. Para o restante, as duas imagens são praticamente iguais (Fig. 2). Curiosamente, a pose da figura em primeiro plano (cozinheiro em um caso e cozinheira no outro), é a mesma: panela na mão direita e mão esquerda no lado do corpo. Só o olhar das duas figuras é visivelmente diferente: a cozinheira olha para o fogão; o cozinheiro, para o lado oposto. Nesse modo, na imagem do texto de Rumpoldt, a figura em segundo plano, que permanece substancialmente inalterada nas duas versões, é dotada de uma maior autonomia e responsabilidade. Em ambos os casos, trata-se de uma mulher que segue o cozimento de um prato em uma panela, e leva uma colher à boca para experimentá-lo.

Peter (2008:7) argumenta que o livro de Rumpoldt é, junto à Opera de Scappi, o epítome da cultura gastronômica ocidental da época. Já foi observado que o autor, cozinheiro de corte em Mainz, dirigia-se também a um público feminino: a imagem na folha de rosto encena essa co-participação de homens $e$ mulheres. ${ }^{51}$ A comparação entre esta imagem e a do livro de Anna

\footnotetext{
50 Veja nota 32.

51 Também na edição que apareceu em Augsburg em 1575, e naquela de 1596 de Ein künstlichs und nutzlichs Kochbuch, de Balthasar Staindl von Dillingen, que como se disse dirigia-se a "Mannen und Frawnpersonen", a imagem na folha de rosto apresenta também uma mulher (ao lado de três homens).
} 
Melhor o cozinheiro?

Wecker, além disso, parece comunicar uma possibilidade perfeita de substituir o grande cozinheiro de corte pela cozinheira mulher.

Totalmente diferente é o caso de Scappi: a Opera é repleta de imagens que ilustram os apetrechos de cozinha e as próprias cozinhas com as pessoas que nelas trabalham. $E$ os sujeitos representados são sempre homens (Fig. 1). A diferença em relação às imagens alemãs é evidente. Não fiz uma comparação sistemática entre as imagens presentes nos vários textos, mas, a partir de algumas enquetes, uma comparação desse tipo parece ser interessante; e os resultados provavelmente poderiam ser menos óbvios e esquemáticos do que se poderia concluir à primeira vista. Por um lado, de fato, um primeiro e rápido reconhecimento das imagens poderia revelar o dualismo entre uma cozinha "nórdica" mais feminilizada e uma cozinha "neolatina" mais masculina. Mas, por outro lado, não faltam, pelo menos nos textos italianos, representações de mulheres. Por exemplo, uma das primeiras obras de cozinha que apareceu impressa, a Opera nova chiamata Epulario [Obra nova chamada Epulário] de Giovanni Rosselli (que utilizou amplamente Mestre Martino), pelo menos na edição de 1517 apresenta na folha de rosto a imagem de uma cozinha em que trabalham seis pessoas, entre as quais duas mulheres (uma segue o cozimento do prato em uma panela grande). ${ }^{52}$ Se mencionei essas imagens é para sugerir uma linha possível de pesquisa, não para tirar conclusões precipitadas. Seja como for, elas parecem bastante relacionadas aos conteúdos dos textos, em grande parte resultantes da experiência concreta dos autores, embora obviamente esta seja uma hipótese a ser verificada.

O discurso parece ser mais complexo quando se consideram outras imagens, isto é, quadros que representam cenas de cozinha. Nos quadros italianos, com efeito, as mulheres são bastante numerosas: para citar apenas um exemplo, a Cucina [Cozinha] de

\footnotetext{
52 Disponível em: http://www.academiabarilla.it/biblioteca-gastronomica/bibliotecagastronomica-digitale/rosselli-epulario.aspx - acesso: fevereiro de 2012.
} 
Vincenzo Campi ${ }^{53}$ ou La cuoca [A cozinheira] de Bernardo Strozzi (Fig. 4). Como avaliar estas imagens? Podem ser tomadas como indício de uma maior presença das mulheres nas cozinhas $(e, e m$ particular, nas cozinhas da elite) no que diz respeito à presença que emerge a partir da análise de outras fontes, e em particular dos receituários? A resposta é problemática. Alguns desses quadros têm um significado alegórico; o de Strozzi, em particular, tinha talvez como objetivo transmitir mensagens simbólicas referentes aos quatro elementos. Desse ponto de vista, os voláteis fariam alusão ao ar, o jarro à água, a mulher à terra $e$ a lareira ao fogo (Luciani, 2005-2006:2-23; Carrossino, s.d.).

Deve ser destacado, depois, que muitos quadros se inspiram mais em outros quadros do que na realidade, e entre os que inauguraram toda uma série de pinturas com cozinheiras e/ou cozinhas há artistas holandeses e flamengos que, provavelmente, tinham diante de si situações diferentes daquelas italianas. Além disso, em muitos casos, o tema inspirador é a narração evangélica de Marta e Maria que, portanto, implica a representação de mulheres. Justamente um Cristo na casa de Marta e Maria, do pintor holandês Pieter Aertsen (1553, Rotterdam, Museum Boymans van Bermingen $)^{54}$, que representa uma cozinha cheia de gente, onde há tanto homens quanto mulheres, constituiria um ponto de referência, direto ou indireto, de toda uma série de representações posteriores de cozinhas e cozinheiras, a partir daquelas dos

\footnotetext{
${ }^{53}$ Vincenzo Campi, Cucina [Cozinha] (1580 ca.), Milão, Pinacoteca di Brera. Disponível em: http://upload.wikimedia.org/wikipedia/commons/d/df/Vincenco_CampiCucina.jpg - acesso: fevereiro de 2012.

${ }^{54}$ Disponível em: http://collectie.boijmans.nl/en/work/1108\%20(OK) - acesso: fevereiro de 2012. Desse artista vejam-se também duas representações de cozinheiras, uma de 1550 conservada no Museu de Palazzo Bianco em Gênova (http://commons.wikimedia.org/wiki/File:Pieter_Aertsen_-_The_Cook_-_WGA00058.jpg) e a outra de 1559 conservada no Musee Royal de Beaux-Arts de Antuérpia (http://commons.wikimedia.org/wiki/File:Pieter_Aertsen___La_cuisini\%C3\%A8re.jpg). Veja também, por ex.: http://www.wga.hu/frames-e.html?/html/a/aertsen/index.html - acesso: fevereiro de 2012.
} 
Melhor o cozinheiro?

flamengos Joachim Beuckelaer ${ }^{55}$, aluno do próprio Aersten, e Marten van Cleve. Além disso, parece que Campi, ao pintar sua cozinha, havia tomado alguns particulares da pintura de van Cleve, enquanto outras imagens (ou presumidas) de cozinhas $e$ cozinheiras são devidas a Giacomo Legi ${ }^{56}$, ativo em Gênova, centro no qual operaram vários pintores flamengos (Luciani, 20052006:7-14).

Imagens presumidas: vários estudiosos argumentam, hoje, que quadros cujo título é La cuoca [A cozinheira] não representam, na realidade, mulheres que ocupam esta função. Em particular, no caso da Cuoca [Cozinheira] de Strozzi, essa conclusão é sustentada por dois argumentos: nos catálogos e nos guias dos séculos XVIII e XIX o título do quadro é Donna che spiuma un'anatra [Mulher que depena um pato], ou Fantesca [Empregada doméstica]; em uma casa de classe social alta - e do ponto de vista da jarra de prata, como é considerada a que é representada - não haviam cozinheiras, mas apenas cozinheiros homens. ${ }^{57}$ Uma conclusão, provavelmente correta, à luz do que escreveram estudiosos como Capatti e Montanari e Muzzarelli ${ }^{58}$, e do que foi escrito nas páginas anteriores deste artigo. Nessa perspectiva, uma representação "realista" daquela que podia ser a divisão do trabalho entre homens e mulheres nas cozinhas italianas das elites do Antigo Regime seria, então, a de Carlo Maria Crespi, hoje no Seminário Episcopal de Parma: uma mulher limpa os legumes, talvez feijões; dois homens cozinham; empregados domésticos (homens) elegantes, em libré, levam os pratos na sala (Fig. 5). Embora essa conclusão, por um lado, seja bastante

\footnotetext{
${ }^{55}$ Ver por ex. http://www.wga.hu/frames-e.html?/html/b/beuckela/index.html - acesso: fevereiro de 2012.

${ }^{56}$ Veja por ex. Carrossino, s.d., http://blue.sagep.it/Redazione/NewsLeggi.asp?ID=12537 - acesso: fevereiro de 2012.

${ }^{57}$ Luciani (2005-2006:24) que retoma uma tese sustentada por P. Boccardo na sua intervenção no catálogo da mostra em Gênova dedicada a Bernardo Strozzi em 1995 (Milano, Electa, 1995); Carrossino, s.d.

${ }^{58}$ Capatti e Montanari (1999:274); Muzzarelli (2003:73).
} 
provável, por outro lado não evita o risco de uma argumentação circular deste tipo: como algumas fontes testemunham que as mulheres, nas cozinhas italianas das elites do Antigo Regime, estavam ausentes ou ocupavam cargos de responsabilidade muito baixa, excluímos que as mulheres presentes nos quadros que representam cozinhas sejam cozinheiras, $e$ as consideramos, quando muito, serviçais. O risco citado só poderá ser definitivamente evitado por uma investigação complementar que pesquise os temas aqui tratados, cruzando fontes diferentes $e$ considerando as diferenças entre áreas geográficas e grupos sociais, inclusive as transformações no tempo. A realidade, de fato, não era absolutamente estática.

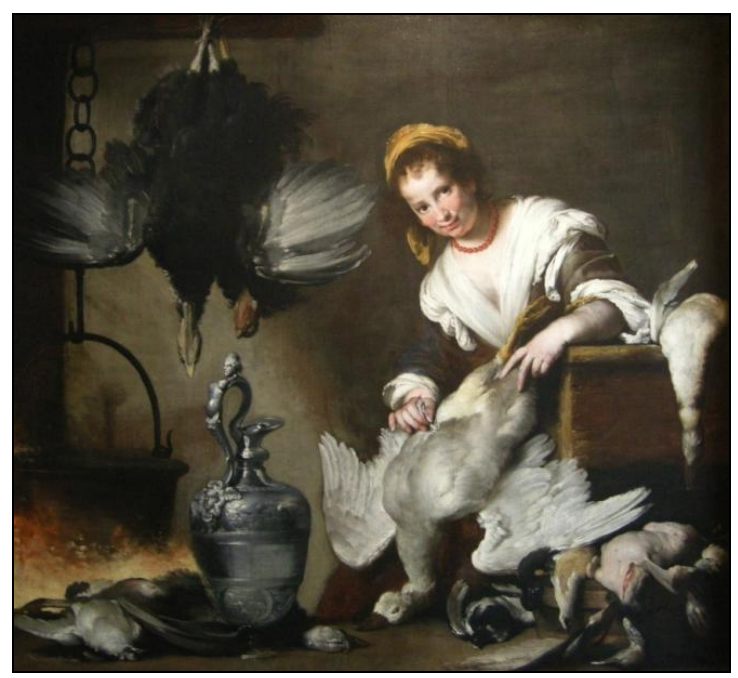

Fig. 4. Bernardo Strozzi, La cuoca [A cozinheira] (1625, ca.), Genova, Musei di Strada Nuova, Palazzo Rosso (C) Musei di Strada Nuova, Genova). Fonte: http://www.arte.it/opera/lacuoca-769 


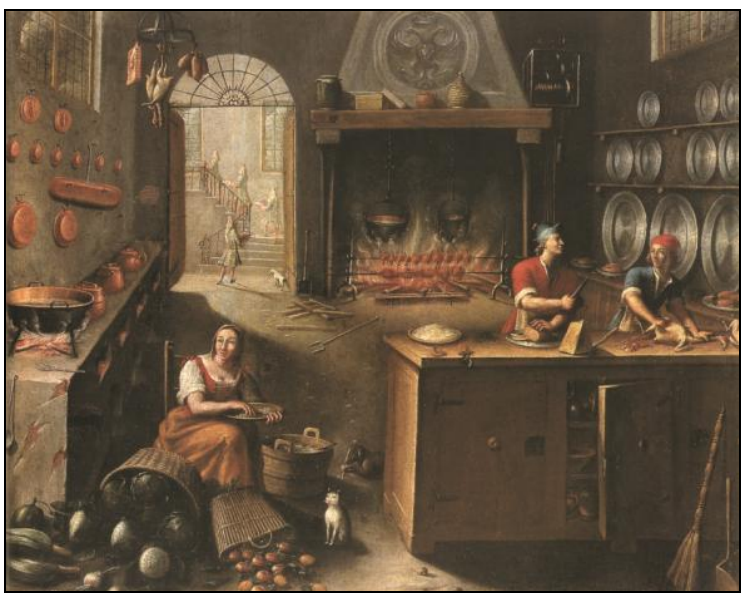

Fig. 5. Carlo Antonio Crespi, Interno di cucina [Interior de cozinha], sec. XVIII, Parma, Seminário Episcopal. Fonte: http://web.tiscali.it/seminariobedonia/pinacoteca_parmigiani.h tm

\section{Transformações de longo prazo}

Voltemos a Tanara. Justamente quando tentava dissuadir seus leitores de utilizar cozinheiras, ele reparava que "na época dos nossos Antepassados, e ainda nos meus primeiros anos, havia nesta Cidade [Bolonha] uma escola de Mulheres, as quais, com muita utilidade e conveniência, sabiam servir na Cozinha, mas hoje em dia é o contrário" (Tanara, 1648:158). Esta afirmação, que suavizava a misoginia das outras páginas da obra do senhor de Bolonha, encoraja-nos a concentrar a análise nas transformações da divisão do trabalho de cozinha entre homens e mulheres durante a Idade Moderna.

Segundo Muzzarelli (2003:35), a cozinha na época medieval era prevalentemente feminina: a masculinização seria realizada junto com a importância crescente que os banquetes assumiram como momento de exibição de poder e riqueza. A hipótese de masculinização do pessoal da cozinha na passagem da Idade Média à Idade Moderna é coerente com os resultados de alguns 
estudos sobre a composição de gênero do pessoal doméstico como um todo. Tais resultados certamente devem ser tomados com cautela, devido à dificuldade de circunscrever o pessoal doméstico, de coletar dados quantitativos e de compará-los ao longo do tempo e do espaço (Sarti, 2005a). Apesar dessas ressalvas, as pesquisas realizadas mostram que em cidades como Florença e Veneza, a partir do século XVI até o final da Idade Moderna, verificou-se uma masculinização do pessoal doméstico (Sarti, 1994a; 1997; 2005b:215-216). Esta masculinização tem sido interpretada de várias formas, sendo reconduzida, no que se refere à fase do século XVI, ora às transformações do mercado do trabalho por causa do crescimento demográfico do período (Klapisch, 1986), ora à aristocratização da sociedade (Romano, 1996:116-117, 228-239) - interpretação que "combinaria" muito bem com as razões apresentadas para apoiar a hipotética masculinização das cozinhas das elites.

No caso de Bolonha, ao qual Tanara se referia, os dados disponíveis indicam que, na época da sua infância, por volta de 1600 (a data do seu nascimento é desconhecida), os servos homens eram aproximadamente $43 \%$ do pessoal doméstico da cidade. Sua incidência parecia estar em queda havia pelo menos doze anos e, de acordo com os dados disponíveis, teria sido assim por outros vinte anos - em 1617 estava reduzida a 38\%. Por isso, é possível que também o pessoal da cozinha tivesse experimentado uma tendência à feminização ou, pelo menos, não tivesse passado por uma tendência à masculinização, ainda que seja necessário enfatizar fortemente que os vários componentes do pessoal doméstico não seguiam todos necessariamente a mesma tendência, se e quando mudavam. Desde os anos vinte do século XVII, os homens no total da servidão provavelmente aumentaram. Em 1631, resultavam 42\%. Depois, por um longo período, não temos informações nem para fazer uma comparação aproximada. No final do século XVIII, uma pesquisa realizada sobre aproximadamente um décimo da população urbana, indica que os homens eram $45 \%$ do total das pessoas de serviço. Entre os 
Melhor o cozinheiro?

domésticos de sexo masculino, cerca de $20 \%$ era constituído por encarregados das comidas e dos vinhos: cozinheiros, segundos cozinheiros, empregados da cozinha, despenseiros, cantineiros, ajudantes de cozinha... Já entre as domésticas de sexo feminino, nenhuma era denominada cozinheira, empregada de cozinha ou nomeada com outros termos que indicassem uma especialização relativa à preparação da comida (Sarti, 1992; 1994a:30-3; 76-77; 8698; 1997; 2004:31). À luz desses indícios espalhados, portanto, parece que no final do século XVIII o mundo das cozinhas bolonhesas era dominado pela presença masculina mais do que no começo do século XVII, como se as sugestões de Tanara tivessem sido levadas a sério ou expressassem opiniões compartilhadas. Mas, obviamente, se trata de uma hipótese de trabalho que deve ser verificada com novas pesquisas, não de uma conclusão.

Supondo que essa hipótese seja justificada, e que a tendência à masculinização seja comum também à França, pátria de muitos grandes cozinheiros, o impulso para a masculinização das cozinhas das famílias de classe elevada, sem considerar aquelas das très grandes maisons, poderia ter sido bastante tardio, se acreditarmos em Charles Duclos que, nascido em 1704, e escrevendo suas memórias em idade avançada (teria morrido em 1772), denunciava o luxo que vira crescer sob seus olhos. Na sua opinião, desde o final do Reino de Luís XIV em diante (o Rei Sol morreria em 1715), ele aumentara mais do que nos dois séculos anteriores, envolvendo também as cozinhas. Até então, de fato, "Não havia, por exemplo, cozinheiros a não ser nas casas de primeira classe. Mais da metade da magistratura se servia apenas de cozinheiras" $"$ (Duclos, 1821:3). Portanto, o forte avanço dos cozinheiros do sexo masculino fora dos círculos mais elitistas terse-ia realizado a partir da segunda década do século XVIII.

\footnotetext{
59 "il n'y avait, par exemple, des cuisiniers que dans les maisons de la première classe. Plus de la moitié de la magistrature ne se servait que de cuisinières".
} 
Justamente a partir da Regência (1715-1723), a cozinha francesa, contudo, começou a mudar, desenvolvendo um gosto por pratos elegantes, sóbrios e delicados. Nos anos trinta $e$ quarenta começou-se a falar de cozinha moderna (Vincent La Chapelle, Le Cuisinier Moderne, $1735^{60}$ ) e de nouvelle cuisine (Menon, Nouveau Traité de Cuisine, vol. 3, La Nouvelle Cuisine, 174261). A nova apreciação pela naturalidade e a simplicidade levou a servir, também nos grandes banquetes, pratos menos complicados do que no passado, e a apreciar a "cozinha burguesa" tradicionalmente preparada pelas donas de casa e pelas suas servas. Nesse contexto, apareceu o primeiro livro de cozinha francês destinado a mulheres, embora o autor fosse um homem. Intitulava-se La Cuisinière bourgeoise. Se for lido à luz da tradição gastronômica francesa, revela, a partir do título, uma oposição entre a cozinha burguesa, feminina, e a cozinha de corte $e$ aristocrática, masculina. A diferença entre a cozinha dos grandes e das famílias de classe "pobre" era explícita no prefácio da obra que, publicada em 1746, era destinada a se tornar um sucesso de vendas: teve sessenta e duas edições em pouco mais de cinquenta anos, por um total de 93.000 cópias, e foi o único livro de cozinha francês do século XVIII publicado também no século seguinte. ${ }^{62}$

\footnotetext{
${ }^{60}$ A primeira edição da obra foi publicada em inglês em 1733 com o título The Modern Cook. O autor, de fato, trabalhava na Inglaterra como chef de Lord Chersterfield.

${ }^{61}$ Menon, La Nouvelle Cuisine avec de nouveau Menus (...) Pour servir de continuation au nouveau Traité de la Cuisine. Tome Troisième, Paris, Joseph Saugrain, 1742.

${ }^{62}$ A primeira edição, que eu não tive a possibilidade de ver, é esta: La cuisinière bourgeoise: suivie de l'office a l'usase [sic] de tous ceux qui se mêlent de dépenses de maisons. Paris, Guillyn, 1746. A citação é retirada da edição que apareceu em Bruxelas, junto François Foppens, em 1760 (Prefácio, páginas não numeradas). Pude verificar que o trecho citado está presente também nas edições que apareceram em 1767, 1783, 1788, 1791, 1793, 1808, 1815. Sobre o livro de Menon, cf. Hyman e Hyman, 1996, mas 1997:509; Mennell, 1985, trad. fr. 1987:117, 123-125.
} 
Seu autor - lia-se no Prefácio - para ser útil às diversas condições, depois de ter dado, em seus primeiros Tratados, preceitos cuja prática pode acontecer apenas nas cozinhas dos Grandes, ou de aqueles que os imitam por meio de uma grande opulência, quis dar preceitos que fossem combinar com as pessoas de uma condição ou de uma fortuna medíocre; e ele fez isso aqui. Ele lhes fornece uma Cozinheira [sic] que, sem custo nenhum, servir-lhes-á para formar à arte dos quitutes, aquelas que eles nutrem e que estão a seu serviço, ou os colocará, a eles mesmos, em condição de as substituírem. Ele acomoda seus preceitos à fortuna deles e à natureza dos alimentos [sic] aos quais essa condição os obriga a se limitarem. Não é mais para os Nobres que ele escreve, senão para os Burgueses: mas pode se dizer que ele enobrece os pratos plebeus usando os temperos $\left[\right.$ sic] para realçá-los. ${ }^{63}$

Era sugerido um jogo complexo no qual, no momento em que se propunha uma imitação da cozinha dos grandes, distanciava-se dela:

Com esses quitutes assim modificados, o olho (pois o Autor o reconhece) será menos satisfeito e o gosto menos provocado: mas em contrapartida, a saúde e o bolso, que merecem pelo menos tanto quanto esses dois sentidos

\footnotetext{
63 "Son Auteur pour se rendre utile aux diverses conditions, après avoir donné dans ses premiers Traités, des préceptes dont la pratique ne peut gueres avoir lieu que dans les cuisines des Grands, ou de ceux qu'une grande opulence met en état de les contrefaire, en a voulu donner qui fussent assortis aux personnes d'une condition, ou d'une fortune médiocre; \& c'est ce qu'il fait ici. Il leur fournit une Cuisiniere [sic], qui, sans rien coûter, leur servira à former dans l'art des apprêts celles qu'ils nourrissent, \& qu'ils tiennent à leurs gages, ou les mettra eux-mêmes en état de s'en tenir lieu. Il accommode ses préceptes à leur fortune, \& à la nature des alimens [sic] auxquels elle les oblige de se borner. Ce n'est plus pour les Nobles qu'il écrit, c'est pour les Bourgeois: mais on peut dire qu'il ennoblit les mets roturiers par les assaisonnémens [sic] dont il les rehausse".
} 
serem poupados, encontraram-se numa situação muito mais confortável. ${ }^{64}$

Revelava-se, assim, uma preocupação pelos custos, ausente na tradição francesa anterior, ao contrário do que acontecia na tradição inglesa, muito atenta ao orçamento (Mennell, 1987:141145). Fato relevante para nós, falando das "cuisinières" que o livro teria instruído, é que o Prefácio assume que nas cozinhas da burguesia, às quais eram destinadas as receitas, havia cozinheiras, assalariadas, de sexo feminino. $\mathrm{Ou}$, pelo menos, pessoas que preparavam suas próprias refeições ("ou les mettra eux-mêmes en état de s'en tenir lieu").

A publicação de um livro como esse, em certa medida, refletia transformações mais gerais das relações entre grupos sociais na França setecentista, e por sua vez contribuía para a mudança. Provavelmente foi possível graças a uma melhoria nos níveis de alfabetização do pessoal de cozinha, que - como demonstram investigações recentes sobre os livros das contas revelava uma certa familiaridade com caneta e papel e com os números (Takats, 2011). O clamoroso sucesso editorial de La cuisinière bourgoise leva à pergunta se e em que modo, naquela época, mudava a composição de gênero do pessoal de cozinha francês. Em outras palavras: a paixão pela (renovada) cozinha doméstica burguesa proposta por Menon que o sucesso de seu livro refletia e incentivava, implicava também maiores chances para as cozinheiras de sexo feminino no mercado do trabalho? Uma fonte analisada por Cissie Fairchilds $(1984: 15-16,51)$ mostra, em Toulouse, no ano de 1695, a presença de 68 cozinheiros e 2 cozinheiras, enquanto em 1789 os homens eram 52, as mulheres 173. Seria interessante, naturalmente, dispor de um dado intermediário para verificar se as denúncias de Duclos citadas

64 "Par ces apprêts ainsi modifiés, l'œil (car l'Auteur l'avoue) sera moins satisfait, \& le goût moins chatouillé: mais en échange, la santé \& la bourse, qui méritent bien pour le moins autant que ces deux sens d'être ménagées, y trouveront beaucoup mieux leur compte". 
Melhor o cozinheiro?

acima tinham fundamento ou não - caso fosse assim, a feminização das cozinhas deveria ter sido um fenômeno do final do século XVIII. Seja como for, em Toulouse, no alvorecer da Revolução, o pessoal especializado da cozinha era constituído por mulheres muito mais do que tinha sido um século antes. Parece plausivel que fosse assim também nas outras partes da França. Admitindo que a reconstrução seja correta, os anos revolucionários acentuaram de modo verossímil o trend para a feminização. Pesquisas recentes sobre as transformações da dimensão de gênero da cozinha durante a Revolução revelam, então, uma nova ênfase nas virtudes da cozinha doméstica republicana: uma cozinha simples, econômica e preparada por mulheres (Davis 2011). Se, por um lado, essa tendência provável contribuía à feminização mais geral do pessoal doméstico evidenciada por vários estudos, do outro parece possível afirmar que - no caso específico dos encarregados para a preparação da comida -, as mulheres muitas vezes substituíam os homens ${ }^{65}$, ao contrário do que estava acontecendo e teria acontecido em outros âmbitos daquele mundo complexo e multifacetado que era o do pessoal de serviço, do qual, na passagem do século XVIII ao século XIX, e depois durante todo século XIX, desapareceram (sem ser substituídas) várias especializações tipicamente masculinas, transferidas para profissionais ou instituições fora da esfera doméstica, ou simplesmente consideradas obsoletas (Sarti, 1992, 1997, 2005a). Falando em substituições, entretanto, não gostaria de dar a ideia de um intercâmbio perfeito entre cozinheiros homens e mulheres: essas substituições, que certamente se tornaram possíveis por uma certa permeabilidade das fronteiras de gênero, provavelmente expressavam e reforçavam modos novos de conceber a cozinha e seus papéis. $\mathrm{E}$ o fato de as cozinheiras

\footnotetext{
${ }^{65}$ Recentemente Takats (2011) salientou os elementos que colocavam no mesmo plano a posição dos cozinheiros e cozinheiras e a fugacidade das fronteiras entre as tarefas de uns e das outras com observações que, se por um lado, em minha opinião, abalam esquemas demasiadamente rígidos, do outro tendem a enfatizar demais as semelhanças em detrimento das hierarquias de gênero.
} 


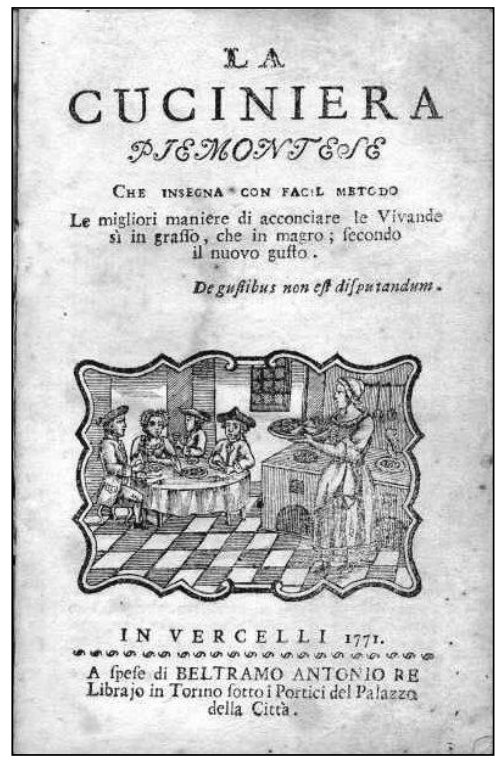
livro de cozinha destinado às mulheres demorou mais ainda. $\mathrm{O}$ volume impresso mais antigo direcionado a um público feminino veio à luz em 1771. Intitulava-se a Cuciniera piemontese, e na página de rosto trazia a imagem de uma mulher perto do fogão que levava um prato a quatro pessoas sentadas ao redor de uma mesa (Fig. 6) ${ }^{66} \mathrm{O}$ prefácio do editor, que justificava a publicação da obra à luz do sucesso do volume anterior Il Cuoco Piemontese (1766), estava concentrado na exaltação dos méritos da cozinha italiana em competição com a cozinha francesa e não explicava as motivações da escolha de criar, com o novo livro, uma espécie de pendant feminino do anterior. Naquela época, entretanto, também

\footnotetext{
${ }^{66}$ Veja a respeito Capatti e Montanari (1999:386), a quem sou devedora pela datação correta dessa obra, cujo título é La cuciniera piemontese che insegna con facil metodo le migliori maniere di acconciare le vivande, Vercelli, Beltramo Antonio Re, 1771. O texto foi republicado pelo menos onze vezes entre 1771 e 1863, cf. Bibliothèque Internationale de Gastronomie, 1994: vol. I, p. 549, n. 608. Da edição de Turim de 1798 há uma reimpressão anastática (Forni, Bologna 1980). Veja também a edição da editora Artistica Piemontese (2000).
} 
Melhor o cozinheiro?

na Itália abria-se caminho à convicção de que era oportuno instruir o pessoal feminino da cozinha. Antonio Nebbia, cozinheiro de Macerata e autor de um receituário de sucesso, dirigindo-se aos leitores esclarecia:

não seja para você causa de maravilha, ó leitor, se me encaminhei a compor este livro de cozinha, enquanto outro objetivo e outra finalidade eu não tive, senão ajudar muitos servos e servas que pretendem, ou pelo menos acreditam, cozinhar bem para seus patrões, e estão quase a jejum nesta profissão. Mas tomei a liberdade de instruí-los com uma facilidade muito grande e com suma clareza, e espero que se tiverem o sofrimento de ler esse meu livro, chegarão a preparar toda espécie de pratos de acordo com o novo sabor, e com economia [...] Isso, com certeza, será para os patrões não apenas motivo de economia, mas de grande satisfação por causa da limpeza, que não deixo e nunca deixarei de recomendar (Nebbia, 1820).

Vontade de instruir não os cozinheiros, mas os servidores que trabalham também na cozinha, homens e mulheres, cuidado com a economia, eram temas semelhantes (exceto o dos servidores homens) àqueles que Hannah Glasse enfrentara mais de trinta anos antes... "Meu método é simples, próprio, e pouco dispendioso", é possível ler na obra La cuoca cremonese (1794), que proclamava ter aprendido o ofício com os cozinheiros da região de Piemonte e com os cozinheiros franceses trabalhando em grandes cozinhas, e propunha-se, portanto, como auctoritas, apesar de ser instruída por homens. ${ }^{67}$ Com efeito, as obras apresentadas como femininas e direcionadas às mulheres na época estavam multiplicando-se. ${ }^{68}$ Em 1801, apareceu um livrinho

\footnotetext{
${ }^{67}$ La cuoca cremonese che insegna a cucinare con facilità qualunque sorta di vivande. Almanacco utile e dilettevole per l'anno 1794. Capatti, Montanari, 1999:278-279.

68 Ao invés disso, o manuscrito setecentista sobre a "cozinha moderna" de um autor anônimo que assinava como Monsieur Guazzetto conservado no Arquivo
} 
dedicado de forma inovadora às mães de família, cujo título era em si mesmo um programa: La cuoca di buon gusto con economia e pulizia. ${ }^{69}$ Folheando o Giornale Italiano, no dia 05 de dezembro de 1815, podia-se ler a propaganda de um almanaque para o ano seguinte, de 1816, intitulado La serva cuciniera e credenziera, vendido em Milão "pelo tipógrafo Pulini, no bairro Bocchetto, ao preço de 50 centavos". ${ }^{70}$ Poucos meses depois, os leitores da Gazzetta di Milano recebiam a informação de que,
devido à esperada venda e contínua procura do almanaque A Serva cozinheira e despenseira dedicado às suas companheiras, em pouco tempo se esgotaram as cópias. Por isso, tendo sido feita uma segunda edição corrigida $e$ melhorada, avisa-se os que desejarem o citado almanaque que este está disponível pela mesma editora Pulini. ${ }^{71}$

Portanto, uma fórmula de sucesso, e de um sucesso duradouro já que muitos anos depois ainda estavam em circulação almanaques com este título ou títulos semelhantes. ${ }^{72}$ Mas se, por um lado,

de Estado de Pisa e recentemente publicado por Addobbati e Lo Castro (2006) era direcionado para um servidor homem.

${ }^{69}$ La cuoca di buon gusto con economia e pulizia: dedicata alle madri di famiglia, Torino, Stamparia Benfa e Ceresola, ano IX republicano (1801). Trata-se de uma obra que não vi pessoalmente, títulos e detalhes provêm do opac (on-line public acess catalogue) do Instituto Central do Catálogo Único.

${ }^{70}$ Giornale Italiano, terça-feira dia 05 de dezembro de 1815, n 339 , p.IV.

${ }^{71}$ Gazzetta di Milano, sábado dia 13 de abril de 1816, p.76. A grafia é a mesma que é relatada no texto.

${ }^{72}$ La serva cuciniera e credenziera. Milano, Bertoni, 1825; L'antica serva cuciniera e credenziera ricorretta dal suo successore il cuoco piemontese ed arricchita di nuove vivande si da grasso che da magro. Milano, da tipografia de comércio, 1829; La nuova serva economica cuciniera e credenziera. Milano, Tipografia Motta agora de M. Carrara, 1840; La nuova serva economica cuciniera e credenziera che prosiegue a dare un assortimento di pietanze di grasso di magro e d'olio..., Milano, Motta, 1845. De todos esses almanaques, só vi o último. 
Melhor o cozinheiro?

desde 1817 um texto atribuído ao cozinheiro Francesco Leonardi apresentava uma locandeira muito capacitada ${ }^{73}$, por outro, a serva cozinheira dos homônimos almanaques custava a conquistar autonomia. Nos anos vinte do século XIX, um dos almanaques homônimos, que não por acaso abria-se com a imagem de uma cozinha onde trabalhavam um homem $e$ uma mulher, apresentava-a "treinada pelo cozinheiro piemontês" (La Serva, 1828). ${ }^{74}$ Já a litografia na edição milanesa do almanaque para o ano de 1845 representava duas mulheres, acompanhada pelo subtítulo "A dona de casa na cozinha" ${ }^{75}$ Enquanto na Alemanha já no texto de Anna Wecker do final do século XVI havia a imagem de duas mulheres (Fig. 3), nos livros de receitas italianos esta era uma das primeiras imagens, se não a primeira em absoluto, na qual eram representadas duas figuras femininas sem nenhuma presença masculina. Por outro lado, talvez seja possível considerar o volume de Giulia Ferraris Tamburini, Come posso mangiar bene, publicado em Milão pela editora Hoepli em 1900, como o primeiro livro de cozinha de verdade que apareceu impresso no nosso país escrito e assinado por uma mulher italiana $^{76}$ (os manuscritos, como vimos, existiam também em épocas muito mais antigas). Certamente, naquela época já eram numerosos os textos escritos por mulheres que tratavam da economia doméstica e da cozinha (Colella, 2003). E a cozinha "doméstica" tivera sua consagração definitiva, no panorama italiano, graças à publicação, em 1891, da primeira edição da obra La scienza in cucina e l'arte di mangiar bene, de Pellegrino Artusi

\footnotetext{
${ }^{73}$ Leonardi, Francesco. Gianina ossia la cuciniera delle Alpi (apud Capatti, Montanari, 1999:279).

${ }^{74}$ Veja-se também, na nota 68, o almanaque milanês de 1829.

${ }^{75}$ La nuova serva economica cuciniera e credenziera (Milano e Motta, 1845). Disponivel em: http:/www.academiabarilla.it/adv/libro/nuova-serva-economica/1.aspx acesso: fevereiro de 2012.
}

${ }^{76}$ Salvatori, 2002; http:/www.academiabarilla.it/biblioteca-gastronomica/bibliotecagastronomica-digitale/ferraris-tamburini-come-posso-mangiar-bene.aspx - $\quad$ acesso: fevereiro de 2012. 
(1891), que nasceu da colaboração entre o próprio Artusi, seu cozinheiro Francesco Ruffilli e sua cozinheira Marietta Sabbatini, e em um diálogo interessante com as senhoras suas conhecidas e, principalmente nas edições sucessivas, com o público das suas leitoras (Capatti e Montanari, 1999:280; Capatti, 2002). A produção impressa feminina das obras de cozinhas, no entanto, apesar de ser rica no momento em que começou, é tardia (Salvatori, 2002).

Os dados coletados para Bolonha mostram, por outro lado, que na cidade emiliana o fenômeno da feminização do pessoal de cozinha foi muito mais tardio do que em Toulouse. Já foi dito que nos fascículos de um censo de 1796, relativos a aproximadamente um décimo da população bolonhesa, não havia nenhuma cozinheira de sexo feminino citada. Nos status animarum da paróquia de San Giovanni in Monte, bastante povoada e habitada por muitos nobres, uma cozinheira é indicada em 1810, mas em 1820 e em 1830 nenhuma é registrada. A situação só muda depois. Em 1850, cozinheiras e mulheres da cozinha eram apenas $2 \%$ dos encarregados para as comidas e os vinhos; em 1857, 10\%, em 1899 48\%. Naquele período (1902), elas são 48\% inclusive na paróquia vizinha de San Bartolomeo, cuja composição social é um pouco mais "burguesa". Talvez, nessa paróquia a feminização seja mais precoce justamente por essa composição social diferente. Já em 1840, cozinheiras e mulheres da cozinha eram só $11 \%$ dos encarregados. Nesse caso também, contudo, não são citadas outras, nem em 1810, nem em 1820 e tampouco em 1830. ${ }^{77}$

Naturalmente - no encerramento desse percurso é bom repetir - o fato de não haver mulheres indicadas como cozinheiras ou encarregadas da cozinha em muitos status animarum examinados, assim como em muitas outras fontes analisadas, não

\footnotetext{
${ }^{77}$ Arquivo de Estado de Bolonha, Legato, Censimento di famiglie distinto per parrocchie (ex notificazione 2 maggio 1796); Arquivo da Paróquia de San Giovanni in Monte de Bolonha, Status animarum, 1810, 1820, 1830, 1850, 1857, 1899; Arquivo da Paróquia dei Santi Bartolomeo e Gaetano de Bolonha, Status animarum, 1810, 1820, 1830, 1840, 1870, 1902. Cf. Sarti, 1992: tabelas $1 \mathrm{a}$ e 1b, p. 248.
} 
Melhor o cozinheiro?

significa que não tinham servas que cozinhassem. Sem dúvida, em Bolonha, como em outros lugares, nas casas com servidão onde não havia cozinheiro, uma ou mais servas genéricas cuidavam também da preparação da comida. Mas uma coisa é cuidar da preparação da comida em meio a outras mil atividades, outra coisa é dedicar-se exclusivamente à cozinha. Em Bolonha, esse processo de especialização das servas mulheres e da substituição, por parte delas, dos cozinheiros homens, parece justamente um fenômeno bastante tardio, em relação a outros contextos europeus. Seria obviamente interessante ter à disposição dados que permitissem entender se a cidade emiliana era representativa da situação italiana como um todo, se representava a exceção ou a regra.

Last but not least [por último, mas não menos importante], vamos olhar, ainda que brevemente, o caso espanhol. $\mathrm{Na}$ Espanha, a publicação de livros de cozinha direcionados a mulheres é ainda mais tardia do que na Itália. O primeiro é provavelmente La cuynera catalana, texto anônimo publicado pela primeira vez em 1835 e destinado, em seguida, a um grande sucesso e várias vezes novamente publicado durante o século XIX e no começo do século XX (Moyano Andrés, 2010:30). Um volume pouco anterior apresenta uma xilografia com uma mulher que serve um prato pronto, dando a impressão de que foi ela que o preparou. ${ }^{78}$ Volumes sucessivos também direcionavam-se em modo mais ou menos explícito (também) a cozinheiras mulheres: El practicón, de Ángel Muro (1894), apresenta, por exemplo, imagens de mulheres no fogão (Abad Zardoya, 2010:102). Deve-se aguardar, entretanto, até 1913 para ver impresso um livro de cozinha escrito por uma mulher - La cocina española antigua, de Emilia Pardo Bazán, que desde 1892 começara a publicação de

\footnotetext{
${ }^{78}$ P.M.T.I., Nou manual de cuinar amb tota perfecció. Nuevo manual de guisar con toda perfección o método de comer bien con poco dinero. Contiene toda clase de guisados de carne, Barcelona, Manuel Texero. 1830. Não vi pessoalmente o volume. Agradeço Carmen Abad Zardoya pela indicação.
} 
uma coletânea de volumes com o título significativo de "Biblioteca de la Mujer" (Moyano Andrés, 2010:35).

\section{Algumas reflexões conclusivas}

Na Idade Moderna, portanto, as diferenças de classe e de cultura tornavam a relação das mulheres com a preparação da comida pouco linear: em todos os lugares entre as classes médiobaixas e baixas, as mulheres, geralmente, amamentavam seus filhos e cozinhavam. Mas no topo da escala social, os cozinheiros eram homens $e$ as mulheres não amamentavam. Entre os diferentes contextos havia, porém, diferenças importantes, pelo que é possível avaliar. Na Inglaterra e na Alemanha, de fato, as mulheres de classe média e alta provavelmente cuidavam da preparação da comida mais do que na França, na Itália e na Espanha. Querendo agora acrescentar uma peça no quebracabeça que aqui se tentou reconstruir, embora provisoriamente, deve-se lembrar que as amas de leite nunca tiveram no solo inglês uma difusão que possa ser confrontada com muitas outras áreas do continente (Itália, França e Espanha em particular); e que na Inglaterra seu declínio foi mais precoce do que alhures. ${ }^{79}$ "Até mesmo as mulheres de uma certa qualidade amamentam os filhos", reparava um viajante estrangeiro em 1784, referindo-se às famílias anglo-saxônicas. ${ }^{80}$ Significativamente, Pietro Verri, um dos primeiros nobres italianos cuja mulher deixou de amamentar, estigmatizado por causa disso pelos pais e parentes, era acusado de querer "bancar o inglês". 81 Apesar de encontrar resistências, o aleitamento materno a partir do final do século XVIII e depois, mais decididamente no século XIX, espalhou-se também entre as

\footnotetext{
${ }^{79}$ Stone, 1983:479-480; Fildes, 1997:135 e 192; Sarasúa, 1994:187-193.

80 Johann Wilhelm von Archenholtz, Tableau de l'Angleterre, apud Stone (1983:479).

${ }^{81}$ Barbagli, 1996:357.
} 
elites italianas, francesas e espanholas. ${ }^{82}$ Portanto, é necessário perguntar-se se há um nexo, e eventualmente descobrir qual é, entre a maior e mais precoce difusão - nas classes privilegiadas inglesas - do aleitamento materno $e$ a atribuição às mulheres, na terra de Albion, das várias tarefas relacionadas com a preparação da comida.

Mas se, mais ou menos a partir do século XVIII em diante, por um lado houve um maior envolvimento das mulheres das elites no aleitamento materno de seus filhos em todos os países europeus, mesmo com as diferenças que foram acenadas, e, do outro, como vimos, verificou-se uma feminização das cozinhas $e$ do mundo dos livros das receitas, talvez seja possível concluir que, a partir daquela época, as várias tarefas relacionadas com a esfera da "nutrição" conjugaram as mulheres de toda a Europa, e de todas as classes sociais, mais do que acontecera anteriormente, a ponto de se tornar um elemento central na definição da feminilidade. Também para as mulheres nobres e ricas, tornar-se mãe significava cada vez mais amamentar os próprios filhos; cada vez mais esperava-se (por aquilo que pode ser verificado a partir da leitura dos livros de cozinha e dos manuais relativos à gestão da casa) que todas as mulheres soubessem cozinhar, seja que preparassem a comida em primeira pessoa, seja que delegassem a tarefa ao pessoal de serviço, que em todo caso tinham que saber controlar $e$ instruir. ${ }^{83}$ Ao mesmo tempo, os homens tendiam a desaparecer das cozinhas nas regiões como a França, a Itália e, presumivelmente, a Espanha, onde por muito tempo os cozinheiros, os encarregados das cozinhas, os despenseiros de sexo masculinos tinham sido os verdadeiros dominadores do

\footnotetext{
${ }^{82}$ Ainda não tenho condições de expressar juízos sobre a situação da amamentação no mundo alemão.

${ }^{83}$ Desse ponto de vista, deverá ser avaliado melhor se iniciativas como a de Hannah Glasse, que visava instruir diretamente os domésticos, conforme a citação anterior ou o relativo sucesso, na Inglaterra, da cozinha francesa entre o fim das guerras napoleônicas e a metade do século XIX implicariam ou implicaram um afastamento das mulheres nobres inglesas das cozinhas.
} 
cenário, enquanto aquelas mesmas cozinhas povoavam-se de um número crescente de cozinheiras.

Certamente, será possível fazer a objeção de que, com o desenvolvimento da industrialização, muitas mulheres das classes populares foram obrigadas a lançar mão das amas; que muitas trabalhadoras, na fábrica, encontraram dificuldades crescentes para preparar a comida e, em um certo sentido, afastaram-se do fogão. De fato, provavelmente é verdade que, enquanto as mulheres da elite se aproximavam, por assim dizer, da esfera da alimentação, muitas trabalhadoras, dentro de certos limites, se afastavam. Mas, quando a ideia de as mulheres serem, em primeiro lugar, nutrizes, conquistou a elite ${ }^{84}$, o fato de muitas trabalhadoras confiarem os próprios filhos a uma ama, e não cuidar da preparação da comida para as suas famílias, foi considerado uma das muitas aberrações que o trabalho fabril causou (Sarti, 2006), enquanto por séculos parecera absolutamente normal que as mulheres nobres deixassem a cozinheiros homens a tarefa de preparar o almoço e, apesar de muitas críticas, não amamentassem os próprios filhos. ${ }^{85}$

Tendo em vista a análise dos comportamentos com os quais, nos diferentes contextos (históricos, geográficos e sociais), é construída a identidade de gênero, o aleitamento e a preparação da comida se revelam, afinal, elementos que não são associados rigidamente, sempre e em todo caso, com a identidade feminina; ao contrário, revelam uma variabilidade e flexibilidade às vezes surpreendente, as quais levam necessariamente à desconstrução de velhos estereótipos, bem como à busca, caso por caso - com um trabalho paciente de dissecção -, das variáveis relevantes e do

\footnotetext{
${ }^{84}$ Por razões de espaço não é possível, aqui, seguir o argumento desta ideia como mereceria; a respeito veja Sarti, 1999, com referências bibliográficas e o ensaio interessante de Colella, 2003. Mais em geral, sobre a construção social do papel materno cf. Fiume, 1995; D'Amelia, 1997.

85 Barbagli, 1996; Pomata, 1980; Fiume, 1995; D’Amelia, 1997.
} 
Melhor o cozinheiro?

modo como essas variáveis se compõem e se nos decompõem diferentes contextos.

\section{Referências bibliográficas}

ABAD ZARDOYA, Carmen. Herramientas curiosas para cosas particulares y extraordinarias. Tecnología, espacios y utillaje en la cocina histórica española. In: La Cocina en su Tinta. Biblioteca Nacional de España, 2010, pp.85-117.

AddobBatti, Andrea e Lo CASTRO, Giuseppe. La cucina di Monsieur Guazzetto. Pisa, Edizioni Ets, 2006.

AdORNI BRACCESI, Simonetta; RAGAGLI, Simone e LANDO, Ortensio. Dizionario Biografico degli Italiani, vol. 63. Roma, Istituto della Enciclopedia Italiana fondata da Giovanni Treccani, 2004. Disponível em:

http://www.treccani.it/enciclopedia/ortensiolando_(Dizionario_Biografico)/ - acesso em fevereiro de 2012.

Ago, Renata. Il gusto delle cose. Una storia degli oggetti nella Roma del Seicento. Roma, Donzelli, 2006.

AlbalA, Ken. Food and Feast as Propaganda in Late Renaissance Italy. In: Kirby, Diane e Luckins, Tanja. (eds.) Dining on turtles: food feasts and drinking in history. Houndmills, Palgrave Macmillan, 2007, pp.3-45.

. Food in Early Modern Europe. Westport, Greenwood Publishing Group, 2003.

ARTUSI, Pellegrino. La scienza in cucina e l'arte di mangiar bene. Firenze, Tip. Di Salvadore Landi, 1891.

BARBAGLI, Marzio. Sotto lo stesso tetto. Mutamenti della famiglia in Italia dal XV al XX secolo. Bologna, Il Mulino, 1996, pp.336-363. [1984]

BASTIANO DI FRANCESCO. La Fantesca composta pfr [sic] Bastiano di Francesco Linaiuolo Sanese. Sopra d'una Donna qual narrando le sue virtù, cerca di trovar padrone. Di nuovo stampata. Sem lugar, sem indicações tipográficas, sem data.

BEMPORAT, Claudio. Cucina e convivialità italiana del Cinquecento. Firenze, Olschki, 2007. 
BENTINI, Jadranka et alii. A tavola con il principe. Materiali per una mostra su alimentazione e cultura nella Ferrara degli Estensi. Venezia, Corbo, 1988.

BERTELLI, Sergio e CRIFÒ, Giuliano. (orgs.) Rituale cerimoniale etichetta. Milano, Bompiani, 1985.

BEST, Michael R. Introduction. In: MARKHAM, Gervase. The English Housewife. A cura di Best, Michael R. McGill-Queen's Universty Press, 2003, pp. XI-LVIII. [1986]

BiBlothÈQUE INTERNATIONALE DE GASTRONOMIE. Catalogo italiano $e$ latino delle opere di Gastronomia, a cura di Bagnasco, Orazio. Sem lugar, Edizioni B.In.G., 3 voll, 1994.

BocK, Gisela. Frauen in der europäischen Geschichte: vom Mittelalter bis zur Gegenwart. München, Beck, 2000 [trad. it. Le donne nella storia europea: dal Medioevo ai giorni nostri. Roma-Bari, Laterza, 2001].

CALVI, Giulia e BerTelli, Sergio, La bocca del Signore... Commensalità e gerarchie sociali fra Cinquecento e Seicento, Metamorfosi, n $7,1983$.

CAPATTI, Alberto. Pellegrino Artusi e la cucina di casa. In: Festa Artusiana. Cultura, gastronomia, mostre mercato, spettacolo, Sesta edizione, Atti del convegno scientifico con spettacolo e uso di cucina "La cucina di casa in Italia, dal Medioevo ad oggi". Forlimpopoli, 22 giugno 2002. Disponível em: http://www.pellegrinoartusi.it/convegniartusiani-2/2002-2/.

CAPATt, Alberto e MONTANARI, Massimo. La cucina italiana. Storia di una cultura. Roma-Bari, Laterza, 1999.

CARrossino, Mariella. Tre cuoche nei musei di Strada Nuova. Disponível em: http://www.sagep.it/easyNews/NewsLeggi.asp?NewsID =12459; publicado também em: Liguria Blue: http://blue.sagep.it/Redazione/NewsLeggi.asp?ID =12460 - acesso: fevereiro de 2012.

CARrossino, Mariella. L'arte dell'abbondanza. Publicação online em: Liguria Blue: http://blue.sagep.it/Redazione/NewsLeggi.asp?ID=12537 acesso: fevereiro de 2012. 
Melhor o cozinheiro?

CAvallo, Sandra. Secrets to Healthy Living: The Revival of the Preventive Paradigm in Late Renaissance Italy. In: LEONG, Elaine $e$ RANKIN, Alisha. (orgs.) Secrets and Knowledge in Medicine and Science, 1500-1800. Farnham-Burlington, VT, Ashgate, 2011, pp.191-212.

. The artisan's casa. In: AJMAR-WOLLHEIM, Marta e DENNIS, Flora. (orgs.) At Home in Renaissance Italy. London, V\&A Publications, 2006, pp.66-75.

Cervio, Vincenzo. Il Trinciante di M. Vincenzo Cervio, ampliato et a perfettione ridotto dal Cavalier Reale Fusoritto. Roma, Gabbia, 1593 [1581]. Reimpressão anastática: Sala Bolognese, Forni, 1980).

Colella. Anna. Figura di vespa e leggerezza di farfalla: le donne e il cibo nell'Italia borghese di fine Ottocento. Firenze, Giunti, 2003.

Cortelazzo, Manlio e Zolli, Paolo. Dizionario etimologico della lingua italiana, vol. I. Bologna, Zanichelli, 1979.

CORTESE, Isabella. I Secreti de la Signora Isabella Cortese. Ne' quali si contengono Cose minerali, medicinali, arteficiose, \& Alchimiche, \& molte de l'arte profumatoria, appartenenti a ogni gran Signora. Venetia, Bariletto, 1561.

CosPI, Antonio Maria. Il giudice criminalista (...) Distinta in tre volumi. Dove con dottrina teologica, canonica, civile, filosofica, medica, storica, e poetica si discorre di tutte quelle cose, che al giudice delle cause criminali possono avvenire. Dato in luce dal dottor Ottaviano Carlo Cospi. Fiorenza, Zanobi Pignoni, 1643 [1638].

Cusatelli, Giorgio. Ucci, ucci. Piccolo manuale di gastronomia fiabesca. Milano, Arnoldo Mondadori, 1994 [1983].

D'AmBrosio, Angelo. Il cibo dei chiostri. Piatti e dolci della tradizione monastica. Terlizzi, Ed. Insieme, 2011.

D'Ambrosio, Angelo e Spedicato, Mario. Cibo e clausura. Regimi alimentari e monastici nel Mezzogiorno moderno (secc. XVII-XIX). Bari, Cacucci, 1998.

D’AmELIA, Marina. (org.) Storia della maternità. Roma-Bari, Laterza, 1997a. 
D'AmEliA, Marina. La presenza delle madri nell'Italia medievale e moderna. In: D'AMELIA, Marina. (org.) Storia della maternità. RomaBari, Laterza, 1997b, pp.2-52.

DAVIDSON, Caroline. A Woman's Work is never done. A History of housework in the British Isles 1650-1950. London, Chatto \& Windus, 1982.

DAVIS, Jennifer J. To Make a Revolutionary Cuisine: Gender and Politics in French Kitchens, 1789-1815. Gender \& History, vol. 23, n 2 , 2011, pp.301-320.

DE BLASI, Nicola. Bastiano di Francesco (Bastiano linaiuolo). In: Dizionario Biografico degli Italiani, vol. 7. Roma, Istituto della Enciclopedia Italiana fondata da Giovanni Treccani, 1970. Disponível em: http://www.treccani.it/enciclopedia/bastiano-di-francesco_(DizionarioBiografico)/ - acesso: fevereiro de 2012.

Della Verde, Maria Vittoria. Gola e preghiera nella clausura dell'ultimo '500. Foligno, Edizioni dell'Arquata, 1988.

DELPIANO, Patrizia. Il governo della lettura. Chiesa e libri nell'Italia del Settecento. Bologna, Il Mulino, 2007.

DEONNA, Waldemar e RENARD, Marcel. Croyances et superstitions de table dans la Rome antique. Bruxelles, Latomus, 1961.

DI SCHINO, June e LUCCICHENTI, Furio. Il cuoco segreto dei papi. Bartolomeo Scappi e la Confraternita dei cuochi e dei pasticcieri. Roma, Gangemi, 2007.

DICKIE, John. Delizia! The Epic History of the Italians and their Food. London, Sceptre, 2007.

DOLCE, Ludovico. Degli Ammaestramenti pregiatissimi Che appartengono alla Educatione, a i Costumi, \& alla honorevole e virtuosa vita virginale, maritale, e vedovile. In: Le Bellezze, le Lodi, gli Amori et i Costumi delle Donne..., Venetia, Barezzo Barezzi, 1622. [1545].

DuClOS, Charles. Mémoires sur la vie de Duclos écrits par lui-même. In: Id., Euvres de Duclos. Tome Premier, İere Partie. Paris, A. Belin, 1821.

DÜRRSCHMID, Klaus. Eine Geschichte des deutschsprachigen Kochbuchs. Wien, 2002. Disponível em <http://homepage.boku.ac.at/duerr/>. 
Melhor o cozinheiro?

ELIAS, Norbert. Über den Prozess der Zivilisation. I. Wandlungen des Verhaltens in den weltlichen Oberschichten des Abendlandes. Frankfurt a. M., Suhrkamp, 1969 [1939].

Evangelisti, Silvia. Nuns. A history of Convent Life. Oxford, Oxford University Press, 2007.

FACCIOLI, Emilio. La cucina. In: Storia d'Italia, vol. 5, I documenti. I. Torino, Einaudi, 1973, pp.983-1030.

FACCIOLI, Emilio. (org.) L'arte della cucina in Italia. Torino, Einaudi, 1992 [1987].

FAIRCHILDS, Cissie. Domestic Enemies. Servants \& Their Masters In Old Regime France. Baltimore-London, The John Hopkins University Press, 1984.

FANTI, Mario. Abiti e lavori delle monache di Bologna in una serie di disegni del secolo XVIII. Bologna, Tamari, 1972.

FERRINI, Vincenzo. Della lima uniuersale de' vitii. Venetia, Gionti, 1607.

FILDES, Valerie. Wet nursing. A History from Antiquity to the Present. Oxford, Basil Blackwell, 1988.

. Breasts, Bottles and Babies. A History of Infant Feeding. Edinburgh, Edinburgh University Press, 1986.

FIORAVANTI, Leonardo. Dello specchio di scientia universale. Nuovamente ristampato, e corretto, e con molte cose aggionte. Venetia, Zaccaria Conzatti, 1660 [1564].

FIUME, Giovanna. Mariti e pidocchi. Storia di un processo e di un aceto miracoloso. Roma, Edizioni XL, 2008 [1990].

. Nuovi modelli e nuove codificazioni: madri e mogli tra Settecento e Ottocento. In: D'AMELIA, Marina. (org.) Storia della maternità. Roma-Bari, Laterza, 1997, pp.76-110.

FIUME, Giovanna. (org.) Madri. Storia di un ruolo sociale. Venezia, Marsilio, 1995.

FLANDRIN, Jean-Louis. I tempi moderni. In: FLANDRIN, Jean-Louis e MONTANARI, Massimo. (org.) Storia dell'alimentazione. Roma-Bari, Laterza, 1997, pp.427-448. 
Flather, Amanda. Gender, Space, and Place. The Experience of Service in the Early Modern English Household c. 1580-1720. Home Cultures, vol. 8, n² 2, 2011, pp.171-188.

. Gender and Space in Early Modern England. Woodbridge, Boydell and Brewer for the Royal Historical Society, 2007.

FONTANA, Aldigherio. La servitù instruita overo instruzione a tutti gl'huomini, che servono, per vivere Cristianamente nella pratica del proprio Esercizio. Milano e Bologna, Ferdinando Pisarri, 1710 [1709].

FRAGNITO, Gigliola. La trattatistica cinque e seicentesca sulla corte cardinalizia. "Il vero ritratto di una bellissima e ben governata corte". Annali dell'Istituto storico italo-germanico in Trento, vol. 17, 1991, pp.135-185.

"Parenti" e "familiari" nelle corti cardinalizie del Rinascimento. In: MuZzARELl, Cesare. (org.) "Familia" del principe e famiglia aristocratica. Roma, Bulzoni, 1988, vol. II, pp.565-587.

FRUGOLI, Antonio. Pratica, e Scalcaria. Roma. Francesco Cavalli, 1638 [1631].

[Glasse. Hannah]. The Art of Cookery made Plain and Easy. London, sem indicações tipográficas, 1774 [1747].

GuevarA (de) Antonio. Libro primo delle lettere (...) tradotte dal S. Dominico di Catzelu. Vinegia, Gabriel Giolito de Ferrari, et fratelli, 1555 [1547].

HEAL, Felicity. Food Gifts, the Household and the Politics of Exchange in Early Modern England. Past \& Present, vol. 199, n 1, 2008, pp.41-70.

HECHT, Joseph Jean. The Domestic Servant in Eighteenth Century England. London-Boston-Henley, Routlegde \& Kegan Paul, 1980 [1956].

Holman, S.R. A New Introduction. In: The Treasury Of Hidden Secrets. A 17th-Century Housewives' handbook of cookery, herbals, and medicine attributed to John Partridge an unabridged reprint of the 1653 edition with a new introduction by S.R. Holman. Cambridge, MA, Rhwymbooks, 2002, pp.1-12.

HYMAN, Philip e HYMAN Mary. La stampa in cucina: i libri di cucina in Francia tra il XV e il XIX secolo. In: FLANDRIN, Jean-Louis e 
Melhor o cozinheiro?

MONTANARI, Massimo. (orgs.) Storia dell'alimentazione. Roma-Bari, Laterza, 1997, pp.501-511.

KAVEY, Allison. Books of secrets: natural philosophy in England, 15501600. Urbana and Chicago, University of Illinois Press, 2007.

KLAPISCH-ZUBER, Christiane. La famiglia e le donne nel Rinascimento a Firenze. Roma-Bari, Laterza, 1988, pp.253-283.

. La famiglia e le donne nel Rinascimento a Firenze. RomaBari, Laterza, 1988, pp.213-252.

La Cocina en su Tinta. Biblioteca Nacional de España, 2010.

La nuova serva economica cuciniera e credenziera che prosiegue a dare un assortimento di pietanze di grasso di magro e d'olio... Milano, Motta, 1845.

La Serva cuciniera e credenziera ammaestrata dal cuoco piemontese. Almanacco per l'anno bisestile 1828. Bologna, Stamperia Cardinali e Frulli, sem data.

LANDO, Ortensio. Commentario delle piu notabili \& mostruose cose d'Italia \& altri luoghi di lingua Aramea in italiana tradotto; con un breve catalogo de gli inventori delle cose che si mangiano \& beveno, novamente ritrovato: ripresa dell'edizione veneziana del 1553. In: SALVATORI, Guido e PAOLA. (orgs.) Bologna, Pendragon, 1994.

LANTERI, Giacomo. Della Economica Trattato. Venetia, Vincenzo Valgrisi, 1560.

LAVEN, Mary. Monache. Vivere in convento nell'età della Controriforma. Bologna, Il Mulino, 2004.

LeHMANN, Gilly. The Cook as Artist? In: WALKER, Harlan. (org.) Food in the arts. Proceedings of the Oxford Symposium on Food and Cookery, 1998. Blackawton, Prospect Books, 1999.

LEONG, Elaine e RANKIN, Alisha. Introduction: Secrets and Knowledge. In: LEONG, Elaine e RANKIN, Alisha. (orgs.) Secrets and Knowledge in Medicine and Science, 1500-1800. Farnham-Burlington, VT, Ashgate, 2011, pp.1-20.

LETT, Didier, MOREL, Marie-France. Une histoire de l'allaitement. Paris, Éditions de la Martinière, 2006. 
LOREDANO, Giovan Francesco. Delle lettere del signor Gio: Francesco Loredano Nobile Veneto. Parte seconda. Divise in cinquantadue capi; e raccolte da Henrico Giblet Cavalier. Geneva, Gio. Herm. Widerhold, 1669 [1653].

LUCIANI, Samantha. Cuochi e cucine nella pittura europea tra Rinascimento e Barocco. Tesi di Laurea, Università degli studi di Bologna, Facoltà di lettere e filosofia, Corso di laurea in DAMS - Arte medievale e moderna, 2005-2006.

MAFFIA, Elisabetta. Donne e cibo tra letteratura e storia. Dimensioni e problemi della ricerca storica, $\mathrm{n}^{\circ} 2,1998, \mathrm{pp} .155-174$.

Malaguti, Raffaella. Le mie cose. Mestruazioni: storia, tecnica, linguaggio, arte e musica. Milano, Bruno Mondadori, 2005.

MANCIULLI, Andrea. Le arti della tavola. In: Istituto Internazionale "F. Datini", Prato, Et coquatur ponendo. Cultura della cucina e della tavola in Europa tra Medioevo ed Età moderna. Prato, Istituto Internazionale "F. Datini", 1997, pp.325-345.

MARKHAM, Gervase. The English Housewife. McGill-Queen's University Press, 2003 [1986].

MATTHEWS GRIECO, Sara. Breastfeeding, Wet Nursing and Infant Mortality in Europe (1400-1800). In: MATTHEWS GRIECO, Sara e CoRSINI, Carlo. Historical Perspectives on Breastfeeding. Firenze, Unicef, 1991, pp.15-62.

MATTIODA, Enrico. Il dilettante "per mestiere". Francesco Albergati Capacelli commediografo. Bologna, Il Mulino, 1993.

MENNELL, Stephen. Français et Anglais à table du Moyen Âge à nos jours. Paris, Flammarion, 1987.

Menochio, Stefano. Delle stuore ouero Trattenimenti eruditi (...) Parte Terza. Venezia, Paolo Baglioni, 1675.

MENON. La Cuisinière Bourgeoise, suivie de l'office, A l'usage de tous ceux qui se mêlent de dépenses de Maisons... Bruxelles, François Foppens, 1760 [1746].

MessisBugo, Christoforo. Libro nuovo nel qual s'insegna il modo d'ordinar banchetti, apparecchiar tavole, fornir palazzi, \& ornar 
Melhor o cozinheiro?

camere per ogni gran principe. Et far d'ogni sorte di vivanda secondo la diversità dei tempi, cosi di carne, come di pesce. Aggiuntovi di nuovo, il modo di saper tagliare ogni sorte di carne, \& uccellami, opera molto necessaria, a maestri di casa, a scalchi, a credentieri, \& a cuochi. Venetia, Lucio Spineda, 1600 [1549].

MiCHEL, Dominique. Vatel et la naissance de la gastronomie. Paris, Fayard, 1999.

MILILLO, Aurora. Il sistema alimentare nelle fiabe popolari europee. Note di gastronomia fiabesca. La ricerca folklorica, 30, 1994, pp.51-58.

MONTANARI, Massimo. Cucina di professione e cucina di casa fra Medioevo e Rinascimento. In: Festa Artusiana. Cultura, gastronomia, mostre mercato, spettacolo, Sesta edizione, Atti del convegno scientifico con spettacolo e uso di cucina "La cucina di casa in Italia, dal Medioevo ad oggi”. Disponível em $<$ http://www.pellegrinoartusi.it/convegni-artusiani-2/2002-2/>.

. La fame e l'abbondanza. Storia dell'alimentazione in Europa. Roma-Bari, Laterza, 1994 [1993].

. Nuovo Convivio. Storia e cultura dei piaceri della tavola nell'età moderna. Roma-Bari, Laterza, 1991.

MONTENEGRO, Riccardo. Abitare nei secoli. Storia dell'arredamento dal Rinascimento ad oggi. Milano, Leonardo Arte, 1996.

MOYANO ANDRÉS, Isabel. La cocina escrita. In: La Cocina en su Tinta. Biblioteca Nacional de España, 2010, pp.17-59.

MuZZARELli, Giuseppina. Il Medioevo e l'età moderna. In: MuZZARELLI, Giuseppina e TAROZZI, Fiorenza. Donne e cibo. Una relazione nella storia. Milano, Bruno Mondadori, 2003, pp.1-100.

NEBBIA, Antonio. Il cuoco maceratese (...) che insegna a cucinare ogni sorta di vivande, tanto di grasso che di magro; imbandir mense secondo la nuova moda, e l'ultimo buon gusto; e finalmente il modo facile di fare allievi di sotto-Cuochi, ed il dover di questi verso i loro respettivi Uffiziali. Opera utile e vantaggiosa Non solo a' giovani Servitori, e Donne di cucina, ma anche a tutti quei, che intendono applicare a simil mestiere. Bassano, Remondini, 1820 [1781; 1779]. 
Niccoli, Ottavia. Storie di ogni giorno in una città del Seicento. RomaBari, Laterza, 2000.

NOTAKER, Henry. Printed cookbooks in Europe, 1470-1700: Bibliography of Early Modern Culinary Literature. Newcastle, DE, Oak Knoll Press, 2010.

OGILVIE, Sheilagh, KüPKER, Markus e MAEGRAITH, Janine. Women and the Material Culture of Food in Early Modern Germany. Early Modern Women: An Interdisciplinary Journal, vol. 4, 2009, pp.149-159.

Overton. Markus et alii. Production and Consumption in English Households, 1600-1750. London-NewYork, Routledge, 2004.

PASTORE, Alessandro. Veleno. Credenze, crimini, saperi nell'Italia moderna. Bologna, Il Mulino, 2010.

$\mathrm{PECH}$, Sarah. L'influence des nourrices sur la formation physique et morale des enfants qu'elles allaitent selon les médecins et moralistes espagnols des XVIème et XVIIème siècles. Paedagogica Historica, vol. 43, n 4, 2007, pp.493-507.

PETER, Peter. Kulturgeschichte der deutschen Küche. München, Beck, 2008.

PICCOLOMINI, Alessandro. Della Institution Morale (...) Libri XII. Venetia, Giordano Ziletti, 1575 [1542].

POMATA, Gianna. Madri illegittime tra Ottocento e Novecento: storie cliniche e storie di vita. Quaderni storici, vol. 15, n 44, 1980, pp.497-542.

REICHENBACH, Johann. Fr. J. Allgemeines Küchenlexicon für Frauenzimmer welche ihre Küche selbst besorgen. Leipzig, Voss, 1794.

RICCI, Piero. "Stare al segno". Ovvero la graziosa gestualità del trinciante. In: RICCI, Piero. Nomi, pieghe, tracce. Studi di semiologia della cultura. Urbino, QuattroVenti, 1994, pp.105-121.

ROMANI, Marzio Achille. Regalis coena: aspetti economici e sociali del pasto principesco (Italia settentrionale, secoli XVI-XIX). In: CAVACIOCCHI, Simonetta. (org.) Istituto Internazionale di Storia Economica "F. Datini", Prato, Alimentazione e nutrizione, secc. 13.18. Atti della ventottesima Settimana di studi, 22-27 aprile 1996. Firenze, Le Monnier, 1997, pp.719-740. 
Melhor o cozinheiro?

ROMANO, Dennis. Housecraft and Statecraft. Domestic service in Renaissance Venice, 1400-1600. Baltimore-London, The Johns Hopkins University Press, 1996.

RUMPOLDT, Marx. Ein new Kochbuch.... Franckfort am Mayn, Johann Saurn, 1604 [1576].

SALVATORI, Paola. I ricettari femminili del primo Novecento. In: Festa Artusiana. Cultura, gastronomia, mostre mercato, spettacolo, Sesta edizione, Atti del convegno scientifico con spettacolo e uso di cucina "La cucina di casa in Italia, dal Medioevo ad oggi".Disponível em $<$ http://www.pellegrinoartusi.it/convegni-artusiani-2/2002-2/>.

SARASÚA, Carmen. Criados, nodrizas y amos. El servicio doméstico en la formación del mercado de trajo madrileño, 1758-1868. Madrid, Siglo XXI de España Editores, 1994.

SARTI, Raffaella. Contando o conto de Zita: as estórias dos servos sagrados e a história dos servos. Varia Historia, vol. 23, n 38, 2007, pp.464-489.

- Lavoro in casa, lavoro fuori casa: riflessioni del tardo Ottocento e di inizio Novecento. Economia \& Lavoro, vol. 40, $\mathrm{n}^{\circ} 1$, 2006, pp.129-146.

. Who are Servants? Defining Domestic Service in Western Europe (16th-21st Centuries). In: PASLEAU, Suzy e SCHOPP, Isabelle e SARTI, Raffaella. (orgs.) Proceedings of the Servant Project. Liège, Éditions de l'Université de Liège, 2005a, vol. II, pp.3-59. Disponível em $<$ http://www.uniurb.it/sarti $>$.

. Conclusion. Domestic Service and European Identity. In:

PASLEAU, Suzy e SCHOPP, Isabelle e SARTI, Raffaella. (orgs.) Proceedings of the Servant Project. Liège, Éditions de l'Université de Liège, vol. V, 2005b, pp.195-284. Disponível em $<$ http://www.uniurb.it/sarti $>$.

. "Noi abbiamo visto tante città, abbiamo un'altra cultura". Servizio domestico, migrazioni e identità di genere in Italia: uno sguardo di lungo periodo. Polis. Ricerche e studi su società e politica in Italia, vol. 18, $\mathrm{n}^{\circ} 1,2004$, pp.17-46. Disponível em $<$ http://www.uniurb.it/sarti $>$. 
- Vita di casa. Abitare, mangiare, vestire nell'Europa moderna. Roma-Bari, Laterza, 1999; trad. portuguesa Casa e Família. Habitar, Comer, Vestir na Europa Moderna. Lisbona, Editorial Estampa, 2001 [tradutora: Isabel Santos]. Disponível em $<$ www.laterza.it $>$.

. Notes on the feminization of domestic service. Bologna as a case study (18th-19th centuries). In: FAUVE-CHAMOUX, Antoinette e FiAlOVA, Ludmila. (orgs.) Le phénomène de la domesticité en Europe, XVIe-XXe siècles (Acta Demographica, XIII). Praha, Ceská Demografická Sociologicky Ústav av CR, 1997, pp.125-163. Disponivel em <http://www.uniurb.it/sarti $>$.

. Per una storia del personale domestico in Italia. Il caso di Bologna (secc. XVIII-XIX). Tese de Doutorado em História (Storia della società europea)», Università degli Studi di Torino, 1994a.

. Zita, serva e santa. Un modello da imitare? In: BARONE, Giulia, CAFFIERO, Marina e SCORZA BARCEllonA, Francesco. (orgs.) Modelli di santità e modelli di comportamento. Contrasti, intersezioni, complementarità. Torino, Rosenberg \& Sellier, 1994b, pp.307-359.

. Servire al femminile, servire al maschile nella Bologna setteottocentesca. In: NAVA, Paola. (org.) Operaie, serve, maestre, impiegate. Torino, Rosenberg \& Sellier, 1992, pp.237-264.

[Schellhammer, Maria Sophia]. Das Brandenburgische Koch-Buch. Berlin-Potsdam, Rüdigern, 1732 ( $\mathrm{I}^{\mathrm{a}}$ ed. com o título de Die wohl unterwiesene Köchinn, 1692; da edição de 1723 há uma reimpressão anastática: Edition Leipzig, DDR, 1984).

SPILLER, Elizabeth. Seventeenth-century English recipe books: cooking, physic and chirurgery in the works of Elizabeth Talbot Grey and Aletheia Talbot Howard. Aldershot, Ashgate, 2008.

STONE, Lawrence. Famiglia, sesso e matrimonio in Inghilterra tra Cinque e Ottocento. Torino, Einaudi, 1983.

Storey, Tessa. Face Waters, Oils, Love Magic and Poison: Making and Selling Secrets in Early Modern Rome. In: LEONG, Elaine e RANKIN, Alisha. (orgs.) Secrets and Knowledge in Medicine and Science, 1500-1800. Farnham-Burlington, VT, Ashgate, 2011, pp.143-163. 
Melhor o cozinheiro?

SWIFT, Johnatan. Directions to Servants in general; and in particular to the Butler, Cook, Footman, Coachman, Groom, House-Steward, and Land-Steward, Porter, Dairy-Maid, Chamber-Maid, Nurse, Laundress, House-Keeper, Tutoress, or Governess. Londres, sem indicações topográficas, 1745.

TAKATS, Sean. The Expert Cook in Enlightenment France. Baltimore, The Johns Hopkins University Press, 2011.

TANARA, Vincenzo. L'economia del cittadino in villa. Bologna, per gli $\mathrm{HH}$. del Dozza, 1648 [1644].

TASSO, Torquato. Dialoghi, II, Il padre di famiglia. In: MAZZALI, Ettore. (org.) Opere, vol. II. Napoli, Rossi, 1969, pp.503-566 [1583].

TAYLOR, Valery. Banquet plate and Renaissance culture: a day in the life. Renaissance Studies, vol. 19, n 5, 2005, pp.621-633.

THORNTON, Peter. Interni italiani del Rinascimento. Milano, Leonardo, 1992.

VISCEGLIA, Maria Antonietta. I consumi in Italia in Età moderna. In: ROMANO, Ruggiero. (org.) Storia dell'economia italiana, II, L'Età moderna: verso la crisi. Torino, Einaudi, 1991, pp.211-241.

WeATHERILL, Lorna. Consumer Behaviour \& Material Culture in Britain 1660-1760. London-New York, Routledge, 1988.

WECKER, Anna, Ein köstlich new Kochbuch. Amberg, bey Michaeln Forstern, 1598 [1597]. Reimpressão anastática Heimeran Verlag, München, 1977.

ZAMA, Piero. Pellegrino Artusi. In: Dizionario biografico degli italiani, vol. 4. Roma, Istituto della Enciclopedia Italiana fondata da Giovanni Treccani, $1962 . \quad$ Disponível em $<$ http://www.treccani.it/enciclopedia/pellegrino-artusi_(DizionarioBiografico)/> - acesso: fevereiro de 2012. 